University of Michigan Law School

University of Michigan Law School Scholarship Repository

\title{
What If? The Legal Consequences of Marriage and the Legal Needs of Lesbian and Gay Male Couples
}

David L. Chambers

University of Michigan Law School, dcham@umich.edu

Available at: https://repository.law.umich.edu/articles/89

Follow this and additional works at: https://repository.law.umich.edu/articles

Part of the Family Law Commons, Law and Society Commons, Legislation Commons, and the Sexuality and the Law Commons

\section{Recommended Citation}

Chambers, David L. "What If? The Legal Consequences of Marriage and the Legal Needs of Lesbian and Gay Male Couples." Mich. L. Rev. 95, no. 2 (1996): 447-91.

This Essay is brought to you for free and open access by the Faculty Scholarship at University of Michigan Law School Scholarship Repository. It has been accepted for inclusion in Articles by an authorized administrator of University of Michigan Law School Scholarship Repository. For more information, please contact mlaw.repository@umich.edu. 


\title{
WHAT IF? \\ THE LEGAL CONSEQUENCES OF MARRIAGE AND THE LEGAL NEEDS OF LESBIAN AND GAY MALE COUPLES
}

\author{
David L. Chambers*
}

Laws that treat married persons in a different manner than they treat single persons permeate nearly every field of social regulation in this country - taxation, torts, evidence, social welfare, inheritance, adoption, and on and on. In this article I inquire into the patterns these laws form and the central benefits and obligations that marriage entails, a task few scholars have undertaken in recent years. I have done so because same-sex couples, a large group not previously eligible to marry under the laws of any American jurisdiction, may be on the brink of securing the opportunity to do so in Hawaii. ${ }^{1}$ I wanted to know the benefits and burdens that legal marriage might extend to this group and ask whether the consequences would be sensible and appropriate for samesex couples. How, in other words, would this institution, molded over time for persons of different sexes, apply to those with different differences?

My findings form the core of this article: that the laws assigning consequences to marriage today have much more coherence than has been commonly recognized, largely falling within three sorts of regulation; that each of these three sorts of regulation would, as a whole, fit the needs of long-term gay male and lesbian couples; that while the law has changed in recent years to recognize nonmarital relationships in a

* Wade H. McCree, Jr., Collegiate Professor of Law, University of Michigan. B.A. 1962, Princeton; LL.B. 1965, Harvard. - Ed. While working on this piece I consulted many friends and colleagues, but I am particularly grateful to Elizabeth Bartholet, Steven Homer, William Rubenstein, and Lawrence Waggoner for their close scrutiny of a draft and for the research assistance of Edward Deibert, Noreen Nash, and Amy Smith.

1. See Baehr v. Lewin, 852 P.2d 44 (Haw.), clarified, 852 P.2d 74 (1993). The court held that Hawaii's law limiting marriage to opposite-sex couples was unconstitutional as an impermissible form of sex discrimination under Hawaii's constitution, unless the state of Hawaii could demonstrate a compelling justification for limiting marriage to opposite-sex couples. As this article was completed, a trial court, after repeated postponements, held a hearing in which the state tried to present evidence of a compelling justification. 
variety of contexts, the number of significant distinctions resting on marital status remains large and durable; that in some significant respects the remaining distinctive laws of marriage are better suited to the life situations of same-sex couples than they are to those of the opposite-sex couples for whom they were devised; and, most broadly, that the package of rules relating to marriage, while problematic in some details and unduly exclusive in some regards, are a just response by the state to the circumstances of persons who live together in enduring, emotionally based attachments. Legal marriage, somewhat surprisingly to a person long dubious of the state's regulation of nonviolent private relationships, has much to be said for it.

I need to make clear what one of my points is not. I do not claim that, if a new legal code of human or family relationships were developed completely afresh, governments should continue to sanctify the two-person enduring union over every other relationship in precisely the manner they do today. Rather, my claim is that, after thousands of years of human history, the union of two persons in a relationship called "marriage" is almost certainly here to stay, that the special rules for married people serve legitimate purposes, and that gay men and lesbians should not shrink from embracing them, nor should politicians shrink from extending them.

Just at the point that I finished this article, Congress acted to limit the effects that legal marriage would have, if Hawaii or any other state moved to permit same-sex couples to marry. The new "Defense of Marriage Act" declares that all federal statutes and regulations that refer to married persons or to spouses shall be read as applying to opposite-sex couples only. ${ }^{2}$ This article persists in reviewing both federal and state laws that bear on married persons, for the purpose of my exercise of imagination — the "what if?" — is not to explore what will actually happen if gay couples are permitted to marry in Hawaii, but rather to ask how opposite-sex married persons are treated under the law today and hold these laws up to the situations of lesbian and gay male couples. By the end of the exercise, the meanspiritedness of Congress's actions may be more apparent, for the rules that it has gone out of its way to deny to same-sex couples are ones that I believe will be shown to be fully applicable to the lives of most gay men and lesbians in long-term relationships.

2. See Defense of Marriage Act, Pub. L. No. 104-199, § 3(a), 110 Stat. 2419, 2419 (1996). 


\section{Postures Toward Marriage}

A large proportion of American adults who identify themselves as lesbian or gay live with another person of the same sex and regard that person as their life partner. Exactly how many gay or lesbian adults there are in the United States and what proportion live with another in a long-term relationship are not possible to calculate on the basis of existing information. Many lesbians and gay men, perhaps most, refuse to identify their sexuality to strangers who ring their doorbell or call them on the telephone. ${ }^{3}$ Still, every survey of adult Americans willing to identify themselves as lesbian or gay finds that a majority or a near majority are living currently with a partner. ${ }^{4}$ Increasing numbers of these couples are celebrating their relationships in ceremonies of commitment. 5 Those who participate commonly refer to the ceremonies as weddings and to themselves as married, ${ }^{6}$ even though they know that the ceremonies are not legally recognized by the laws of any state. If states extend the legal right to marry, it is highly probable that large numbers of gay and lesbian couples would choose to participate. In a recent survey of nearly 2600 lesbians, for example, seventy percent said

3. In one effort to survey Americans in every state by phone, it took 1650 calls to Kansas - 55 hours of random dialing - before the pollers found the first person willing to admit being lesbian or gay. See Larry Hatfield, Methods of Polling, S.F. ExAMINER, June 5, 1989, at A-20. It is possible, of course, that fewer than one-tenth of one percent of Kansans are lesbian or gay, but I doubt it.

4. The largest attempt at a random national sampling of Americans willing to identify as lesbian or gay was by a private polling group in 1989 for the San Francisco Examiner. See id. In that survey, $64 \%$ of lesbians and $60 \%$ of gay men said that they were currently in a relationship. The median length of that current relationship was 2.3 years. See Larry D. Hatfield, New Poll: How U.S. Views Gays, S.F. EXAMINER, June 6, 1989, at A-19. In large surveys of its readership by the Advocate, $67 \%$ of lesbians and $44 \%$ of gay men reported themselves currently in a relationship with a primary partner. See Janet Lever, Lesbian Sex Survey, ADvocate, Aug. 22, 1995, at 29; Janet Lever, The 1994 Advocate Survey of Sexuality and Relationships: The Men, ADvoCATE, Aug. 23, 1994, at 23.

5. The Advocate reports that $46 \%$ of women and $30 \%$ of men said that they had exchanged rings or had a commitment ceremony. See Lever, Lesbian Sex Survey, supra note 4, at 29; see also Suzanne Sherman, Introduction to LESBIAN AND GAY MARRiage: Private Commitments, Public Ceremonies 1, 5-7 (Suzanne Sherman ed., 1992) [hereinafter Lesbian and Gay MarRiage]; Ceremonies of THE HearT: Celebrating Lesbian Unions (Becky Butler ed., 1990).

6. See Lesbian AND GAY MARRIAGE, supra note 5, at 13 (providing a collection of interviews with lesbian and gay male couples who have joined in ceremonies of commitment; most of the couples referred to themselves as married and the ceremony as a wedding). 
they would marry another woman if same-sex marriage were legally recognized. ${ }^{7}$

Exactly what lesbians and gay men hope to obtain from legal marriage is uncertain. Since public ceremonies of commitment are already so common, one might expect that when debating state-sanctioned marriage, they would focus on what law itself can accord that other institutions cannot: a range of legally protected benefits and legally imposed obligations. In fact, they do not. In the vigorous public discussion, few advocates address at any length the legal consequences of marriage. William Eskridge, for example, devotes only six of the 261 pages in his fine new book, The Case for Same-Sex Marriage, to the legal consequences, and his, with one exception, is the longest discussion I can find. ${ }^{8}$ Whatever the context of the debate, most speakers are transfixed by the symbolism of legal recognition. It is as if the social significance of the marriage ceremonies gay people already conduct today count for nothing - as if, without the sanction of the state, those who marry have merely been playing dress-up.

That the social meanings of state recognition draw so much attention is nonetheless understandable. In our country, as in most societies throughout the world, marriage is the single most significant communal ceremony of belonging. It marks not just a joining of two people, but a joining of families and an occasion for tribal celebration and solidarity. In a law-drenched country such as ours, permission for same-sex couples to marry under the law would signify the acceptance of lesbians and gay men as equal citizens more profoundly than any other nondiscrimination laws that might be adopted. Most proponents of same-sex marriage, within and outside gay and lesbian communities, want marriage first and foremost for this recognition. ${ }^{9}$ Most conservative oppo-

7. See Lever, Lesbian Sex Survey, supra note 4, at 27 . In a comparable survey of gay men, $59 \%$ said that they would marry if they could, and another $26 \%$ said maybe. Seventy-one percent of men said they preferred long-term monogamous relationships. See Lever, Advocate Survey, supra note 4, at 23-24. In the national telephone survey undertaken for the San Francisco Examiner, $92 \%$ of lesbians and gay men indicated approval when asked, "How do you feel about two people of the same sex living together as a married couple?" See New Poll, supra note 4, at A-21.

8. See William Eskridge, THE CASE for SAme-Sex Marriage 66-71 (1996); see also HAWAII COMMISSION ON SEXUAL ORIENTATION AND THE LAW, REPORT 1-23 (1995) (discussing the legal consequences of marriage at greater length).

9. See EsKRIDGE, supra note 8; Thomas Stoddard, Why Gay People Should Seek the Right to Marry, OUT/LOOK, NATL. GAY AND LESBIAN Q. Fall 1989, at 9, reprinted in LESBIAN AND GAY MARRIAGE, supra note 5, at 13; Evan Wolfson, Crossing the Threshold: Equal Marriage Rights for Lesbians and Gay Men and the Intracommunity Critique, 21 N.Y.U. Rev. L. \& SoC. ChaNGE 567 (1994-95); Nan D. Hunter, Marriage, Law, and Gender: A Feminist Inquiry, 1 L. \& SEXUALITY Summer 1991, at 9. 
nents oppose it for the same reason. Thus, the conservative legislators who have promoted the recent legislation in many states that reject same-sex marriage and the members of Congress who voted for the Defense of Marriage Act ${ }^{10}$ seem motivated not by a view of the inappropriateness of extending particular legal entitlements to same-sex couples but by views about some "inherent" meaning of marriage and by views about the social unacceptability of gay people and gay relationships.

Skeptics about marriage within the lesbian and gay communities also largely ignore the legal consequences of marriage. They focus instead on the negative meanings they attach to the institution itself. To many, marriage signifies hierarchy and dominance, subjugation and the loss of individual identity. ${ }^{11}$ To them, it marks a tombstone over the graves of countless generations of married couples: one stone reads "Herbert Smith," the other simply reads "Wife." And even if the legal institution of marriage has changed in the recent past, they resist the assimilation of queer couples into an oppressive heterosexual orthodoxy of ascribed roles and domesticity. ${ }^{12}$

When skeptics about marriage within lesbian and gay communities do focus on the legal consequences of marriage - and they occasionally do - some express considerable misgivings. In the introduction to her collection of interviews with lesbians and gay men who have united in ceremonies of commitment, Suzanne Sherman writes with admiration of the couples she encountered, but also expresses doubts about marriage as a legal institution: "I don't believe that tax breaks and other benefits should be attached to marital status." 13 In her view, the subject of the law ought to be the individual, not the couple. Many of her interviewees seemed to agree. They treasured their partners, but expressed distrust of the state. If state laws permitted same-sex marriage, many

10. In the wake of the decision of the Hawaii Supreme Court, sixteen states have adopted laws declaring that their state does not recognize same-sex marriages even if conducted validly in another state or that, for their state's purposes, the only valid marriages are marriages of a man and a woman. See Forum on the Right to Marry (visited Aug. 12, 1996)<FORUMBOSTON@aol.com>; see also Ronald Smothers, Mississippi Governor Bans Same-Sex Marriage, N.Y. TIMEs, Aug. 24, 1996, at A6. For the federal statute, see supra note 2.

11. See Paula Ettelbrick, Since When is Marriage a Path to Liberation, OUT/LOOK, NATL. GAY AND LESBIAN Q., Fall 1989, at 9, reprinted in LESBIAN AND GAY MARRIAGE, supra note 5, at 20; Steven K. Homer, Against Marriage, 29 HARv. C.R.-C.L. L. REv. 505 (1994); Nancy D. Polikoff, We Will Get What We Ask For: Why Legalizing Gay and Lesbian Marriage Will Not "Dismantle the Legal Structure of Gender in Every Marriage," 79 VA. L. REV. 1535 (1993).

12. See Ruthann Robson, Lesbian (OUt)law: Survival UNDER the Rule OF LAW 124-27 (1992); sources cited supra note 11. 2.

13. Sherman, Introduction to LESBIAN AND GAY MARRIAGE, supra note 5, at 1, 
said that they would marry to obtain the benefits now given to oppositesex couples, but the tone of their comments sometimes suggested that the bounty that accrues to married people is undeserved or inappropriate. ${ }^{14}$ They speak of it in much the same way that they might speak of the perks of the overpaid chief executive of a large corporation.

Nancy Polikoff, a law professor and scholar who is critical of efforts by gay and lesbian advocates to pursue legalized marriage, views the benefits that attach to heterosexual marriage in much the same way. Of the economic benefits, she writes:

For those who support lesbian and gay marriage because it would allow us access to the package of benefits now associated with heterosexual marriage ... advocating lesbian and gay marriage is an obvious choice. I do not share that vision. Advocating lesbian and gay marriage will detract from, even contradict, efforts to unhook economic benefits from marriage and make basic health care and other necessities available to all..$^{15}$

Polikoff alludes to health care as a specific example of a social good that she believes is inappropriately linked to marital status. She chooses her example well. She and many others, including myself, believe that a wealthy industrialized state should seek to assure decent health care to all individuals in their own right and not derivatively through a spouse or parent. ${ }^{16}$ But health care is only one among dozens of contexts in which married people are treated in a distinctive manner in this country. Looking across the broader range, most gay and lesbian writers about same-sex marriage disagree with Polikoff. ${ }^{17}$ Without devoting much space to their positions, most accept the appropriateness of attaching legal consequences to marital status and conclude that the benefits of marriage would be of enduring value to gay and lesbian couples. This article considers both questions more closely.

\section{The legal Consequences of Marriage}

Each of the fifty states defines the incidents of marriage for its residents. Federal laws add hundreds of other legal consequences. Some scholars have characterized the multitude of legal attributes of marriage

14. See, e.g., LESBIAN AND GAY MARRIAGE, supra note 5, at 108, 146.

15. Polikoff, supra note 11, at 1549; see also Homer, supra note 11, at 515-16.

16. In fact, access to health care has been "hooked" to marital status in this country largely by the action of private employers, not because it has been mandated by governments.

17. See sources cited supra note 15 . For a response to Polikoff's arguments about health care, see Wolfson, supra note 9, at 604-08. 
today as largely incoherent, ${ }^{18}$ and in their details they surely are. Yet, for all the variation among laws, it is possible to identify three central categories of regulation, within each of which a certain coherence obtains: some laws recognize affective or emotional bonds that most people entering marriage express for each other; some build upon assumptions about marriage as creating an environment that is especially promising or appropriate for the raising of children; and some build on assumptions (or prescriptive views) about the economic arrangements that are likely to exist (or that ought to exist) between partners. The review that follows makes no attempt to describe all of these regulations but provides central examples of each sort.

As you read, you will encounter occasional ghosts from an authoritarian and formally gendered past. The laws dealing with married persons have undergone a massive transformation during the last century. ${ }^{19}$ Well into the nineteenth century, all assets of a married couple, including those that the wife brought into a marriage, were controlled by the husband. In fact, her personal property became his property. The husband also, as a matter of law, controlled all decisions that related to a married couples' children. Many of these laws continued well into this century. In many states, for example, as late as the 1950 s, the state of a married woman's residence was fixed by law as the state of her husband's residence. If the husband unilaterally decided to move "his" family to another place without consulting with his wife and the wife chose not to come with him, she became subject to divorce for desertion. ${ }^{20}$ This male-controlled relationship was also difficult or impossible to leave. At the beginning of the nineteenth century, marriage was indissoluble under the laws of nearly all states. Later in the century, it was dissoluble, but only on proof by one sinless spouse of a serious

18.

[C]ontemporary marriage cannot be legally defined any more precisely than as some sort of relationship between two individuals, of indeterminate duration, involving some kind of sexual conduct, entailing vague mutual property and support obligations, a relationship which may be formed by consent of both parties and dissolved at the will of either.

1 Homer H. Clark, JR., The Law of Domestic Relations in the United STATES $\S 2.1$, at 81 (2d ed. 1988).

19. For a history of the early law, see MARYLYNN SALMON, WOMEN AND THE LAW OF PROPERTY IN EARLY AMERICA (1986). For accounts of the changes, see Mary Ann Glendon, The Transformation of Family Law (1989); Mary Ann Glendon, The New Family and the New Property (1981); MaX RheinsteIn, Marriage Stability, DivorCe, and the LAW (1972); Carl E. Schneider, Moral Discourse and the Transformation of American Family Law, 83 MiCH. L. REV. 1803 (1985).

20. See ClARK, supra note $18, \S 4.3$, at $268-69$; see also Franklin v. Franklin, 77 N.E. 48 (Mass. 1908). 
marital sin committed by the other. The partners could not end their relationship and remarry even if they both wished to do so.

Today, legislatures or judicial decisions have removed virtually all rules that explicitly provide different status or authority for husbands. They also permit marriage to end without proof of marital fault. The compulsory and sex-linked aspects of the law of marriage have, during the latter half of this century, been withering away, ${ }^{21}$ sometimes at the price of providing insufficient protection to women economically illpositioned to protect themselves. For many women in opposite-sex marriages, the promise of equality and autonomy remains largely empty, because other social and institutional structures within our culture continue to enforce their subordination. ${ }^{22}$ As we will see, for example, the rules of divorce commonly treat marriage as a partnership with an equal division of property, but, because of their lower earnings, women are generally left significantly worse off financially than men are. Most gay and lesbian couples can, however, appropriately regard the legal aspects of marriage today as serving primarily, though not entirely, a facilitating function - offering couples opportunities to shape satisfying lives as formal equals and as they, rather than the state, see fit. ${ }^{23}$

\section{A. Regulations that Recognize Emotional Attachments}

Some laws and regulations dealing expressly with married persons can best be viewed today as promoting the emotional attachments that most spouses feel toward each other. There are not a great many such laws. And among the handful are some that plainly have historical origins in a time when legislatures and judges conceived of marriage not primarily as a romantic bond but rather as a construct for the control of property and progeny. Still, for this article - the purpose of which is to reveal the current functions that laws of marriage serve - these rules can best be seen as facilitators of the affective aspects of couples' relationships.

Here are a few examples. Statutes or common law doctrine in all states grant decisionmaking powers to relatives when a person becomes incompetent to make decisions for herself. Two broadly different sorts

21. See, e.g., GLendon, The Transformation of Family LaW, supra note

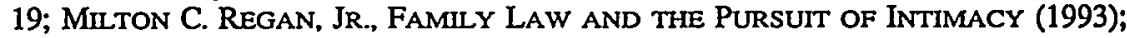
Mary Ann Glendon, Marriage \& the State: The Withering Away of Marriage, 62 VA. L. REV. 663 (1976); Schneider, supra note 19.

22. See Martha albertson fineman, The Illusion of Equality: The RHETORIC AND REALITY OF DIVORCE REFORM 36-52 (1991).

23. See Carl E. Schneider, The Channelling Function in Family Law, 20 HoFSTRA L. REv. 495, 497 (1992) (discussing the facilitative function of American family law). 
of laws exist. The more narrow sort authorizes a family member to make an emergency medical decision when a person has become incompetent and has failed to execute a formal document authorizing some other person to make decisions on her behalf. When such incapacity arises for an unmarried person, state laws designate a parent or an offspring or some other blood relation as decisionmaker, but, for persons who are married, they typically turn first to the person's spouse. ${ }^{24}$ The second sort of law, broader in scope, provides for the formal appointment of a "guardian" or "conservator," who typically makes not only medical decisions but other decisions about residence, care, and financial matters. These statutes also differ widely, but commonly provide first for the appointment of a blood relative for a single person and a spouse for a married person. The Uniform Probate Code, for example, has been adopted in fourteen states, and establishes an order of preference for the appointment of relatives as the guardian for an incapacitated person, with the spouse first in line, followed by an adult child or a parent. ${ }^{25}$ Upon death, other laws or court decisions provide that the spouse has first right as "next of kin" to claim a person's remains ${ }^{26}$ and to make anatomical gifts of parts of the deceased person's body when the deceased person has made no directive of her own. ${ }^{27}$

In a similar manner, state laws designate the spouse as the person to receive part or all a married person's assets when he or she dies without a will. ${ }^{28}$ These "intestacy" laws vary widely among the states. ${ }^{29}$ In some states, if there are surviving children, a spouse receives as little as a third; in many others, a fixed dollar amount and a share of the re-

24. See, e.g., KY. REv. STAT. § 311.631 (Michie Supp. 1994) (listing, in order, the spouse, an adult child, a parent).

25. See UNIF. PROB. CODE $\S 5-305$ (c) (guardian of the person), § 5-409(a) (guardian of property), 8 U.L.A. 466, 487-88 (1983); see also Amy L. Brown, Note, Broadening Anachronistic Notions of "Family" in Proxy Decisionmaking for Unmarried Adults, 41 HASTINGS L.J. 1029, 1045-47 (1990).

26. See, e.g., New Mexico Disposition of Dead Bodies Act, N.M. STAT. ANN. § 24-12-1 to -4 (Michie 1994).

27. See UNIF. ANATOMICAL GIFT ACT $\S 3($ a), adopted in some form in every state; see also N.Y. PuB. HEALTH LAW § 4301(2) (McKinney 1996).

28. See M. HenNER, A COMPENDIUM OF State STAtUtes and INTERNATIONAL TREATIES IN TRUST AND ESTATE LAW (1985). The rules about intestate succession also reflect legislative views about the financial obligations of spouses to each other. See infra section III.C.

29. As a starting point, intestacy laws "build upon the rules that allocate original ownership" during the marriage. Lawrence W. Waggoner, Marital Property Rights in Transition, 59 Mo. L. REv. 21, 27 (1994). As we will discuss later, two quite different regimes of marital property ownership exist within the United States. See infra text accompanying notes $115-20$. 
mainder; in still others, the entire estate.$^{30}$ In most states, if there are no surviving children and no surviving parents, the spouse receives everything. ${ }^{31}$

The laws relating to incompetency and death serve fairly obvious functions but ones worth explicit recognition. Some relate to the control of property, a subject taken up later. But most fundamentally, for couples who see themselves in an enduring relationship, the spouse is the appropriate person for the state to designate as decisionmaker during a period of incompetency and as primary beneficiary after death on the basis of a reasonable guess that that is the person whom the nowincompetent or deceased person would have chosen if she had addressed the question in advance. ${ }^{32}$ That is, the rule fulfills her probable wishes. When commentators criticize the current intestacy rules, they do so primarily on the ground that, in many states, the rules give a surviving spouse less than the evidence suggests that most people would want their spouse to receive. ${ }^{33}$ As to decisionmaking about medical and financial matters, the spouse is also more likely than any other person to know what decisions the incompetent person would have made if she were now able to decide for herself or, alternatively, at least to be the person most concerned about the incompetent person's welfare. Although many spouses rarely discuss such forbidding contingencies, the state surely has available to it no other more appropriate person to designate as the default decisionmaker.

Do gay men and lesbians with partners need the protection of such laws to ensure that their partners make decisions for them or inherit their estates? A very few states designate a long-term unmarried partner as the most preferred decisionmaker for the incompetent person, but

30. See Mary Louise Fellows et al., Public Attitudes About Property Distribution at Death and Intestate Succession Laws in the United States, 1978 AM. B. Found. RES. J. 319, 357-58 nn.128-29; Waggoner, supra note 29, at 37-38 (describing changes in the Uniform Probate Code in 1990 providing that the spouse receives the entire estate even when there are surviving children, so long as the children are the children of the decedent and the surviving spouse has no descendants who are not the decedent's).

31. In Europe and the United States, intestate succession laws have progressively moved toward reducing or excluding shares for blood relatives when the person who died has a surviving spouse. See Glendon, The Transformation of Family LAW, supra note 19 , at $238-40$.

32. The drafters of the Uniform Probate Code, for example, explicitly sought to ground intestacy rules on their best estimation of what people who do not write wills would most prefer. See Waggoner, supra note 29, at 29, 36-38.

33. See Fellows et al., supra note 30 , at 351 (noting that in a phone survey of 750 married persons in 5 states, $71 \%$ said that they wanted their surviving spouse to inherit their entire estate.). 
most states ignore the unmarried partner altogether. ${ }^{34}$ Similarly, only a very few states provide that an unmarried partner shall receive any portion of the estate of a person who dies without a will and, to date, no state provides anything for a same-sex partner..$^{35}$ Despite this, one could argue that gay couples do not need such protections because they can protect themselves fully by simply executing a will or a medical power of attorney. But gay men and lesbians who are in relationships need these protections for the same reason that heterosexual persons need them. Like most heterosexuals, ${ }^{36}$ most gay men and lesbians are reluctant to think about their mortality and procrastinate about remote contingencies. They fail to execute wills and powers of attorney, even though they are often aware of the unfortunate consequences of failing to act. $^{37}$

These consequences are often doubly unfortunate for gay men and lesbians with partners. When they fail to write a will or execute a power of attorney, the consequence is not simply that the state will decline to choose as decisionmaker or heir the person in the world they

34. Section Five of The Uniform Health-Care Decisions Act (1993) gives priority over everyone except a spouse to "an individual in a long-term relationship ... . with the patient in which the individual has demonstrated an actual commitment to the patient similar to the commitment of a spouse and in which the individual and the patient consider themselves to be responsible for each other's well being." As of 1996, the Act had been adopted in a few states. See, e.g., N.M. STAT. ANN. \& 24-7A-5B(2) (Michie Supp. 1996). Arizona has recently adopted a statute that provides that a patient's "domestic partner" can be designated by a court as the surrogate decisionmaker for an incompetent person, but such a person is given lower priority than an adult child or a parent. See ARIZ. Rev. Stat. ANN. \& 36-3231 (1995).

35. Oregon treats in the same manner as a surviving spouse a person who for the 10 years preceding the decedent's death was in a relation with the decedent in which they "mutually assumed marital rights, duties and obligations," although they must also acquire a reputation as "husband and wife." OR. REV. STAT. § 112.017(2) (1995); see also Waggoner, supra note 29. Waggoner is the reporter for the Uniform Probate Code and has recently recommended that intestate successions laws be amended to provide for unmarried partners whose relationship is well-documented or convincingly demonstrated. See id. at 78. Professor Waggoner has recently prepared a further revised version that he can provide by request, at the University of Michigan Law School.

36. See Fellows et al., supra note 30, at 337-39 (reporting that in a survey of 750 adults, 55\% of those interviewed said that they did not have a will, and laziness was the most commonly cited reason).

37. See Karen Thompson \& Julie Andrzejewski, Why Can't Sharon KOWALSKI COME HOME? (1988) (relating the story of Sharon Kowalski, a young woman who had failed to execute a power of attorney before a severely debilitating car accident, and whose lover was excluded by Sharon's parents from playing any role in her care). One of the gay men interviewed by Suzanne Sherman who had united with a partner in a ceremony of commitment said, "We haven't put together a will yet, but we're planning to do it," and his partner conceded, "we won't get motivated until something forces us to." They had been married for five years. LESBIAN AND GAY MARRIAGE, supra note 5, at 208. 
(probably) most trust and love. It is also that the persons who will make the decisions or inherit - most probably biological parents or siblings - are more likely than for heterosexual persons to be estranged from the gay person. In the context of medical decisions, when a gay person is disabled, the biological relations who will make decisions are more likely than for heterosexual persons to decline even to consult with the partner. $^{38}$

Even if all persons with a same-sex partner remembered to execute the proper documents and had access to the needed legal services, other forms of government regulation that recognize special emotional and spiritual ties could not be similarly handled by a scheme of private designations. Consider four examples. Federal law places severe restrictions on the opportunities for foreign-born nationals to immigrate legally to the United States. One significant exception to this rule of exclusion is that a foreign-born national who enters into a nonfraudulent marriage with an American citizen has a presumptive right to enter the United States immediately as a long-term resident. ${ }^{39}$ No such special provisions are made for a friend or lover. Even brothers or parents of a U.S. citizen are not automatically entitled to preferential treatment, but typically face long waiting periods before entry. Recent changes proposed by a Congressional commission would widen the difference between the favored treatment of the noncitizen spouse and the treatment of other relatives a citizen would wish to bring in - retaining the full advantages for the spouse and for minor children, but ending all preferences for siblings and adult children. ${ }^{40}$ The lover is still left out. The spousal preference is a reflection in law of the profound social significance attached to marriage, a relationship that transcends national boundaries.

Another federal law, the Family and Medical Leave Act of 1993, requires all employers with fifty or more employees to extend unpaid leave of up to twelve work weeks during each year to an eligible em-

38. See Rhonda R. Rivera, Lawyers, Clients and AIDS: Some Notes From the Trenches, 49 OHo ST. L.J. 883 (1989). Moreover, even when gay persons do execute a will or power of attorney, blood relatives may be more likely to challenge their competence in making the documents and more likely to allege that their lover had exercised improper influence. See id. at 892; Jeffrey Sherman, Undue Influence and the Homosexual Testator, 42 U. PITT. L. REV. 225 (1981).

39. See 2 Charles Gordon ET AL., ImMigration LAw AND Procedure, $\S 36.02$ (1996). There is also a narrow context in which marriage hurts. Under current rules, an American citizen can secure a preference for entry as a resident for his foreign-born child, if, but only if, the child is not married. See id. § 36.04[2].

40. See U.S. COMMN. ON IMMIGRation Reform, Legal IMmigration: SETTING PRIORITIES 48-75 (1995). 
ployee to care for a spouse with a "serious health condition." 41 The statute also provides for leaves to care for children and for parents, but makes no provision of any kind for friends, lovers, or unmarried partners.

The federal government and many states also extend an advantage to married people when called to testify in a criminal proceeding that bars the state from forcing a married person to testify against his or her spouse. ${ }^{42}$ Nearly all states offer a related protection, typically in both civil and criminal proceedings, for confidential communications made between spouses during the marriage. ${ }^{43}$

Finally, under the law of many states, if a third person injures a married person negligently and by so doing deprives the spouse of care and companionship, the spouse can typically sue the injuring party for what is called loss of "consortium," compensation not for financial loss but for the loss of companionship. ${ }^{44}$

The immigration preference for spouses, the family leave provisions, the evidentiary rules, and the consortium rules have a common current justification: that it is fitting for the state to recognize the significance in people's lives of one especially important person to whom they are not biologically related. The rules both recognize roles that already exist - the spouse as soulmate, caretaker, and confidant - and reinforce the legitimacy of the performance of those roles. Lesbians and gay men in long-term relationships attribute a similar level of importance to their partners ${ }^{45}$ (even if they have other gay and lesbian friends they also consider significant). ${ }^{46}$ They need these rules as much as heterosexual people do. It may well be, for example, that only a small proportion of American lesbians and gay men will wish to marry a foreign national and bring that person back to live in the United States, but, for those who do, it is hard to imagine a more important governmental benefit.

41. See 29 U.S.C. $\$ \S 2611-2654,2612(a)(1)(C)$ (1994).

42. See KenNeth S. Broun ET AL., MCCORMICK ON EvidenCE $§ 66$ (John William Strong ed., 4th ed. 1992); see also Milton C. Regan, Jr., Spousal Privilege and the Meanings of Marriage, 81 VA. L. REV. 2045, 2052-54 (1995).

43. See BROUN ET AL., supra note $42, \S \S 78-86$, at 112-119.

44. See 1 ClARK, supra note $18, \S 12.5$, at $672-83$.

45. Measuring attachment or love is difficult, of course, since scientists have not yet developed an attachometer. For what it's worth, lesbians, gay men, and heterosexuals in long-term relationships score at similarly high levels on standardized instruments asking questions about their liking or love of their partners. See Letitia Anne Peplau, Lesbian and Gay Relationships, in HOMOSEXUALITY: RESEARCH IMPLICATIONS FOR PUBLIC PolicY 177, 181-83 (John C. Gonsiorek \& James D. Weinrich eds., 1991).

46. See generally Kath Weston. Fammies We Choose: Lesbians, Gays, KINSHIP 117-29 (1991); LESBIAN AND GAY MARRIAGE, supra note 5. 
Gay men and women would experience as a burden, not as a benefit, a few regulations that attach to marriage and that also build, in substantial part, on assumptions about the emotional salience of the marital relationship. Public and private employers, for example, adopt antinepotism regulations that prohibit employees from participating in decisions to hire, promote, or discharge their spouse or from supervising their spouse in the workplace. ${ }^{47}$ Resting on views about both emotional and economic ties, these regulations are as justifiably imposed on lesbians and gay men in enduring relationships as they are on heterosexuals: no one can be expected to be sufficiently objective when decisions about one's own long-term partner must be made.

Similarly burdensome, at least for some couples, are old laws that make adultery a crime ${ }^{48}$ and old laws that make adultery a ground for divorce in the states that retain both fault and no-fault grounds..$^{49}$ Many lesbians and gay men will find state-imposed fidelity repugnant on more than one ground. They will do so in part because they reject the notion of criminalizing any voluntary sexual conduct between adults. ${ }^{50}$ They will also reject the legitimacy of state-dictated terms of the intimate relationship between partners. Most gay men and lesbians within couples prize loyalty and fidelity, but many would resist the notion that the test of fidelity - indeed the sole test in the law — turns on whom one has sex with. Many gay men and lesbians, particularly gay men, explicitly disavow sexual exclusivity within their long-term relationships. ${ }^{51}$ Thus, in those states that still have rules relating to adultery, some lesbians and gay men may find their taint a significant impediment to embracing legal marriage. As a practical matter, these rules are

47. See, e.g., 5 U.S.C. $\$ 3110$ (1994) (prohibiting any federal official from employing, promoting, or advancing any of a list of family members in or to a position in an agency in which he serves or over which he exercises control); TENN. CODE ANN. § 8-31-103 (1993) (prohibiting state employees from being placed in the direct line of supervision of a relative).

48. See, e.g., ALA. CoDE § 13A-13-2 (1994).

49. See Linda D. Elrod \& Timothy B. Walker, Family Law in the Fifty States, 27 FAM. L.Q. 515, 661 (1994) (listing 30 states that retain fault grounds as an alternative way to obtain a divorce).

50. Hence, all gay organizations oppose sodomy laws.

51. See DAvid P. MCWhiRTer \& ANDrew M. Mattison, The Male Couple 252-59 (1984) (noting that in a study of 172 male couples, only seven couples had a totally monogamous sexual relationship); see also PHILIP BlumsteIN \& PEPPER SCHWARTZ, AMERICAN COUPLES 271-72 (1983) (finding that, among heterosexual couples, $75 \%$ of husbands and $84 \%$ of wives believed it was important to be monogamous; $71 \%$ of lesbians in couples thought so as well, but only $36 \%$ of gay men in couples considered it important to be monogamous). For some couples, enforced exclusivity might weaken rather than strengthen their bonds to their partners. See id. at 299302. 
rarely invoked today - prosecutors bring almost no criminal cases for adultery and the great majority of divorcing spouses rely on no-fault grounds - but the emblematic meaning of these old rules may still be troublesome.

\section{B. Regulations Dealing with Parenting}

Gay male and lesbian couples raise children in this country in three common contexts. In the first, numerically the most common, one of the partners has already become the biological parent of a child (usually in the course of a prior relationship with a person of the opposite sex) and then has later formed a relationship with a same-sex partner. This new partner is functionally in the position of a "stepparent." In the second context, a same-sex couple, after beginning a relationship, agree to raise a child together. They plan that one of them will be the biological parent and that, after birth, they will serve as co-parents. In the third context, a same-sex couple seeks to adopt or to become the foster parents of a child who is biologically related to neither of them.

Opposite-sex couples also raise children in each of these sorts of contexts and, in each, laws and practices in all states treat such couples, when married, in specially favored ways. By contrast, in each of the three situations, a gay or lesbian partner who is not the biological parent of the child typically faces formidable, often insuperable, difficulties in becoming recognized as a legal parent at all. The laws that advantage married couples are needed by some heterosexual married couples who wish to raise children, but these same laws would be helpful to almost all lesbian and gay male couples who wish to raise a child as legal equals because, for them, it is always the case that neither partner or only one is the biological parent of the child..$^{52}$ Oddly, in the writings of others on the consequences that legal marriage would offer for samesex couples, almost no attention is given to the special rules regarding parenting. ${ }^{53}$

I will discuss each of these three contexts separately. In each, most of the rules would be defended today as intending to serve the best interests of children. I will focus on the value of these rules both for children and for lesbian and gay male adults who wish to raise children. As to the interests of children, a great deal has been written on the ade-

52. Two lesbians may each be biological parents of a single child when one contributes the egg and the other performs gestation. Even here there is necessarily a third biological parent.

53. Eskridge, for example, devotes only two sentences to laws regarding parenting. See ESKRIDGE, supra note 8, at 67. 
quacy of gay men and lesbians as parents in the past two decades, much of it suffering from the inevitable difficulty of identifying random samples of gay persons for any purpose. I do not intend to review this literature. It is well reported elsewhere. ${ }^{54}$ In overwhelming measure, it concludes that a person's sexual orientation has no significant bearing on her or his parenting capacities or skills and that children raised by lesbian and gay male parents fare as well day by day and over time as children raised by other parents. 55 For purposes of this essay, I simply assume that the parenting capacities of gay and lesbian couples have been established.56

As we will see, some of the difficulties currently experienced by gay men and lesbians who wish to raise children are not formally imposed by law. Some arise under rules that courts and agencies already have the discretion to extend to gay people or to same-sex couples, but rarely do. Thus, in some contexts, the benefits of legal marriage for same-sex couples may lie less in the rules that would become applicable to them than in a changed attitude toward homosexual persons that

54. For a brief review, accessible to lawyers, of the research on gay men and lesbians as parents and for abundant references to the social science literature, see Gregory M. Herek, Myths About Sexual Orientation: A Lawyer's Guide to Social Science Research, 1 L. \& SEXUALITX 133, 157-61 (1991); see also Charlotte J. Patterson, Children of Lesbian and Gay Parents, 63 CHILD DEv. 1025 (1992). On lesbians as parents, see Nancy D. Polikoff, This Child Does Have Two Mothers: Redefining Parenthood to Meet the Needs of Children in Lesbian-Mother and Other Nontraditional Families, 78 Geo. L.J. 459 (1990). On gay men as parents, see Frederick W. Bozett, Gay Fathers: A Review of the Literature, 18 J. OF HoMOSEXUALITY 137 (1989).

55. See Patterson, supra note 54. Here, for example, is a very recent capsule statement summarizing research on lesbians as parents:

Researchers who compared children raised in lesbian and heterosexual households found few or no differences in the development of gender identity, genderrole behavior, or sexual orientation. Studies have also found no deficits among children of lesbian mothers in other aspects of personal development, including separation-individuation, locus of control, self-concept, intelligence, or moral judgment. In addition, numerous studies have shown that children raised by lesbians have normal, healthy relationships with other children as well as with adults. According to Patterson's . . . comprehensive literature review on lesbian and gay families, a child's adjustment is enhanced when the lesbian mother lives with her partner, when the lesbianism is acknowledged before the child reaches adolescence, and when the child has contact with peers from other lesbian families.

Nanette Gartrell et al., The National Lesbian Family Study, 66 AM. J. OF ORTHOPSYCHIATRY 272, 272-73 (1996) (citations omitted).

56. A second question that bears on some issues - such as whether to permit gay and lesbian couples to adopt a child that is biologically related to neither - is whether the breakup rate of gay and lesbian couples is so high that whatever preference is accorded to married heterosexual couples as couples should not be accorded to gay and lesbian couples. I can find no figures yet on the average duration of relationships of same-sex couples who have performed ceremonies of commitment or consider themselves married. 
a change in marriage laws might help bring about on the part of legal actors exercising authorities that already exist. Here the symbolic and the legal intertwine.

\section{The Stepparent Relationship}

When a lesbian or gay male parent with custody of a child begins to live with another person of the same sex, the new person assumes a parenting role functionally comparable to a stepparent. The state of the law about such parenting relationships outside of marriage is clear: no matter how long the gay "stepparent" lives with the child, no matter how deeply she becomes involved in the care of the child, she and the child will rarely be recognized as having a legally significant relationship with one another. ${ }^{57}$ The state of the law is essentially the same for stepparent figures in opposite-sex unmarried couples. They are just the "boyfriend" or "girlfriend" or "live in" of the custodial parent and have no legal significance.

Perhaps surprisingly, until the recent past, the legal position of the opposite-sex partner who marries a custodial parent has been little different. In all but a few states, the stepparent married to a biological parent has not been legally obliged to contribute to the support of the child during the marriage..$^{58}$ In no state has the stepparent been required to contribute to the child's support upon divorce, no matter how long he lived with the child or the extent of his voluntary contributions. The stepparent has also had no legal entitlement upon divorce to be considered for court-ordered visitation or for sole or joint custody of the child. ${ }^{59}$ It has been the absent biological parent who remained financially liable for support, who remained the one parent eligible for visitation (even if he never lived with the child), and who remained second in line for custody.

Recently, however, stepparents married to a custodial parent are coming to be recognized as parent figures for at least some purposes, and it is to the benefits of these laws and court decisions that gay and

57. To be sure, the biological parent may designate the partner in her will as the preferred guardian for the child upon her death, a preference that will often be honored by the court unless the other biological parent demands custody.

58. See Margaret M. Mahoney, Stepfammies and tHe LAw 13-51 (1994). Utah, for example, is a partial exception, imposing a duty of support during the course of the stepparent's marriage to the biological parent, but not at the point of divorce. See UTAH CODE ANN. § 78-45-4.1 (1992); see also David L. Chambers, Stepparents, Biologic Parents, and the Law's Perceptions of "Family" After Divorce, in DivorCE REFORM AT THE CROSSROADS 102, 108-09 (Stephen D. Sugarman \& Herma Hill Kay eds., 1990).

59. See MAHONEY, supra note 58, at 124-48 (1994). 
lesbian "stepparents" need access. A few states have begun, for example, to protect the relationship between a child and a stepparent whose marriage to the biological parent comes to an end. No state has imposed on the stepparent a general obligation of support upon divorce, but some courts and a few legislatures have given courts the authority to grant visitation and, in unusual circumstances, custody, even over the objection of the biological parent. ${ }^{60}$

States have also expanded the opportunities for stepparents during their marriage to a biological parent to become the full legal parent of a stepchild through adoption. If the absent biological parent consents, most states permit the married stepparent to adopt without any of the home visits and family studies usually required as a part of the adoption process. ${ }^{61}$ Consensual stepparent adoptions now account for over half of all adoptions that occur in the United States. ${ }^{62}$ Within the last few decades, most states have recognized certain circumstances in which stepparents living with and married to a biological parent are permitted to adopt even over the objection of the absent biological parent. ${ }^{63}$ They have done so in circumstances in which the absent parent is found to have abandoned his relationship with the child by failing to visit or, in some states, willfully failing to pay support. Whichever route a stepparent takes to adoption, at the point the adoption occurs, the biological parent ceases to have any legally recognized relationship to the child and the adopting parent assumes all the rights and responsibilities. ${ }^{64}$

A further change regarding stepparents is found in laws relating to employment in the labor force. State worker's compensation programs ${ }^{65}$ and the federal Social Security survivor benefit program ${ }^{66}$ permit a minor stepchild living with and dependent upon a stepparent to receive benefits after the stepparent's death. These programs replace much of the income lost to a child upon the death of the supporting stepparent. Similarly, the Federal Family and Medical Leave Act of 1993 requires

60. See id.

61. See Joan H. Hollinger, Introduction to Adoption Law and Practice, in ADOPTION LAW AND PRACTICE § 1.05(2) (Joan H. Hollinger ed., 1990).

62. See Joan H. Hollinger, Consent to Adoption, in ADOPTION LAW AND PRACTICE, supra note $61, \S 2.10(3)$.

63. See id.; see also Chambers, supra note 58, at 102, 118-21.

64. See 2 CLARK, supra note $18, \S \S 21.1$, at 565 .

65. See id. $\$ 21.12$, at 688-89.

66. See Margaret M. Mahoney, Stepfamilies in the Federal Law, 48 U. PrrT. L. REv. 491, 496-514 (1987); Mary Ann Mason \& David W. Simpson, The Ambiguous Stepparent: Federal Legislation in Search of a Model, 29 FAMILY L.Q. 445, 457-60 (1994). 
employers to permit a worker to take up to twelve weeks of unpaid leave to care for their seriously ill child, including a stepchild. ${ }^{67}$

Despite these reforms that apply to stepparents married to a biological parent, unmarried stepparent figures, of the same or opposite sex as the custodial parent, remain almost totally ignored by the law, wholly ineligible, for example, for the special treatment for stepparent adoption, wholly unable to secure for a child the benefits of workers' compensation or Social Security survivor benefits, and ineligible for the protections of the Federal Family and Medical Leave Act. They also remain free of the legal obligations that would come with adoption most notably the obligation to provide financial support for the child they adopt - but these are obligations that many gay and lesbian stepparent figures would be pleased to accept. Extending these benefits and obligations to lesbians and gay men by permitting them to marry would serve well their needs and the needs of their children for the same reasons that they serve the needs of married opposite-sex couples and their children: children who live with a stepparent figure who is in a committed relationship with their biological parent often become attached to and financially dependent upon the stepparent, and these attachments warrant recognition. To be sure, for the benefit of children, states might also wisely recognize the strong emotional attachments that children develop to persons to whom their parent is not married but, until the law so expands, the recognition of legal marriage for same-sex couples at least will offer greater protection to one group of children today.

\section{Artificial Insemination, Sperm Donors, and Surrogacy}

The second parenting context for gay men and lesbians includes the same-sex couple, already formed, who agree that one of them will become the biological parent of a child whom they will raise together. Here the issues are rather different for women than for men.

When a lesbian couple plan that one of them will become pregnant - and large numbers of lesbian couples have babies today in this manner ${ }^{68}$ - they first must find a source of sperm. Some face problems that are not formal barriers of law but that are probably aggravated by the

67. See 29 U.S.C. $\$ \S 2611(12) \& 2612(a)$ (d) (1994). The act includes "stepchild" but does not define the term. I assume from its use in other legal contexts that, for purposes of the act, a stepchild is a child of a person to whom the employee is actually married and does not include the child of a person with whom the employee is cohabiting outside of marriage.

68. See generally April Martin, The Lesbian and Gay Parenting Handbook: Creating and Raising our Families (1993); Cheri Pies, Considering PARENTHOOD (2d ed. 1988). 
outlaw status of their relationship. Sperm banks in all states provide insemination services to women, most commonly in circumstances in which the woman is married and her husband is sterile. While no state expressly prohibits sperm banks from providing services to unmarried women or to lesbians, ${ }^{69}$ some doctors and sperm banks apparently decline to do so. ${ }^{70}$

Clearly legal problems arise after birth, at the point that the lesbian partner seeks to become recognized as a legal parent. ${ }^{71}$ She will be able to achieve such recognition only if she successfully completes a formal process of adoption. In most states, her petition to adopt will be rejected, either because her partner and she are of the same sex, ${ }^{72}$ or because they are not married to one another, ${ }^{73}$ or both. In a growing number of states, the lesbian partner can be considered for adoption, ${ }^{74}$ but even in these states, the best the couple can hope for is that, after completing elaborate forms and enduring an intrusive home study and an individualized inquiry into the child's "best interests," a court eventually, many months after the child's birth, will approve the application of the nonbiological parent to adopt. ${ }^{75}$ The whole process is likely to cost thousands of dollars.

69. A 1983 opinion by the Attorney General of Oklahoma concluded that artificial insemination of an unmarried woman is illegal in Oklahoma. See Linda J. Lacey, The Law of Artificial Insemination and Surrogate Parenthood in Oklahoma: Roadblocks to the Right to Procreate, 22 TuLSA L.J. 281, 284-86 (1987).

70. See Martin Curie-Cohen et al., Current Practice of Artificial Insemination by Donor in the United States, 300 NEw ENG. J. MED. 585 (1979) (reporting on a survey of physicians, 90 percent of whom said that they would not perform artificial insemination on an unmarried woman); Caroline H. Sparks \& Jean A. Hamilton, Psychological Issues Related to Alternative Insemination, 22 PROF. PsYCHOL. 308, 311-12 (1991) (reporting that lesbians often face especial difficulties obtaining services from clinics).

71. For a discussion of the difficulties the nonbiological partner experiences when not accepted as a prospective parent during her partner's pregnancy, see Barbara $M$. McCandlish, Against All Odds: Lesbian Mother Family Dynamics, in GAY AND LESBIAN PARENTS 23 (Frederick W. Bozett ed., 1987).

72. Florida and New Hampshire prohibit adoptions by gay men and lesbians. See Fla. STAT. ch. 63.042(3) (1995); N.H. REv. STAT. ANN. § 170-B:4 (1994). In a few other states, appellate courts have declared homosexuals unsuitable to be adoptive parents. See Marla J. Hollandsworth, Gay Men Creating Families Through Surro-Gay Arrangements: A Paradigm for Reproductive Freedom, 3 AM. U. J. GENDER \& L. 183, 197 n.53 (1995).

73. See, e.g., In re Adoption of T.K.J. and K.A.K., Nos. 95CA0531, 95CA0532, 1996 WL 316800 (Colo. Ct. App. June 13, 1996) (holding that only a person married to the biological partner is eligible for the rules regarding stepparent adoption).

74. See Maxwell S. Peltz, Second-Parent Adoption: Overcoming Barriers to Lesbian Family Rights, 3 Mich. J. GENDER \& L. 175, 182-87 (1995).

75. See, e.g., Adoption of Tammy, 619 N.E.2d 315, 317 (Mass. 1993) (noting that the Department of Social Services had conducted a home study and that over a dozen 
Lesbian couples need a simpler and more welcoming process. They need, at a minimum, the procedures available in most states to legally married couples in comparable circumstances. For such couples, most states' laws provide a straightforward procedure governing artificial insemination through clinics or sperm banks. ${ }^{76}$ The sterile husband simply acknowledges in writing his concurrence in his wife's insemination and his acceptance of the child as his own. He is then treated for purposes of the law in exactly the manner that he would be if he had been the biological father. No home study is required. No court hearing is held. The child's birth certificate simply records him as the father of the child. Lesbian couples need access to the same automatic registering of parenthood for the nonbiological female partner. Once the state gets beyond the idea that lesbians are doubtful as parent-figures (or less than full citizens), an individualized inquiry into the "best interests of the child" is no more appropriate for them than it is for opposite-sex married couples.

One aspect of current law relating to artificial insemination would continue to pose problems for lesbian couples even if they were permitted to marry and given access to the comfortable rules described above for fertilization through a sperm bank. Some lesbian couples prefer to use a donor who is known to them and to perform the insemination privately without the sperm bank as intermediary. ${ }^{77}$ When opposite-sex married couples in which the husband is sterile rely upon a donor known to them, they do not qualify for the automatic birth registration system that applies when they make use of a regulated sperm bank, and the legal position of the husband and the donor may be open to doubt. ${ }^{78}$

witnesses testified in support of adoption); In re Jacob, 660 N.E.2d 397, 405 (N.Y. 1995); Adoption of B.L.V.B. and E.L.V.S., 628 A.2d 1271, 1272 (Vt. 1993).

76. See Lori B. Andrews, Alternative Reproduction and the Law of Adoption, in ADOPTION LAW AND PRACTICE, supra note $61, \S 14.02$ (noting that thirty states have adopted statutory rules that a properly consenting husband becomes the legal father for all purposes, and that courts in most other states have reached the same result by relying on the common law presumption of legitimacy for children born within marriage and on the agreement of the parties prior to conception.).

77. See Elizabeth Noble, Having Your Baby by Donor Insemination: A COMPLETE RESOURCE GUIDE 160-96 (1987).

78. In many states, the common law rule that forbids a husband from challenging the legitimacy of a child conceived during a marriage would, if carried over in its application to same-sex marriages, protect the legal status of the nonbiological parent. In some states, however, a failure to comply with the requirements of the artificial insemination statute have led courts not to impose child support obligations upon divorce on the husband. See, e.g., Jhordan C. v. Mary K. \& Victoria T., 224 Cal. Rptr. 530 (Cal. Ct. App. 1986); In re Witbeck-Wildhagen, 667 N.E.2d 122 (Ill. App. Ct. 1996) (deciding a case in which the husband expressly disapproved of the wife's seeking artificial insemination); McIntyre v. Crouch, 780 P.2d 239 (Or. Ct. App. 1989). 
Exactly what scheme of regulation is wisest in the case of donors outside the anonymous donor system is vexing, for whenever the donor knows the parents, the possibility exists that he will want to assert a right to a visiting or other relationship with the child, and there is much debate over the desirability of giving courts authority to order such relationships over the objections of the principal caregivers. ${ }^{79}$ The important point here is that these issues remain vexing whether or not the parenting couple is same-sex or opposite-sex and whether the couple is married or not and that, whatever their resolution, lesbian couples and opposite-sex couples should be treated in the same way, for the children being born to these couples need the same sorts of opportunities and protections.

Similarly problematic are the situations for gay male partners when they wish one of them to serve as the biological father for a child they plan to raise together. ${ }^{80}$ This situation is troublesome for it necessarily involves a much more substantial involvement by the other biological parent - the surrogate mother - than in the case of artificial insemination through a surrogate father, involvement under circumstances in which there are well-founded concerns for the interests of the mother and of women in general. ${ }^{81}$

Reflecting differing resolutions of these concerns, state laws vary widely today regarding the legality and enforceability of surrogacy arrangements. Some prohibit surrogacy agreements altogether; some refuse to enforce them but do not prohibit the arrangements if voluntarily carried out; and some permit enforcement if the parties comply with various state-imposed requirements and if the mother does not change her mind within a statutorily prescribed period. ${ }^{82}$ Among the requirements in many states is that only married couples may enter into surrogacy arrangements with a donor mother. ${ }^{83}$ Thus, under these varying schemes, few gay men could legally enter into an enforceable surrogacy agree-

79. See Brad Sears, Winning Arguments/Losing Themselves: The (Dys)functional Approach in Thomas S. v. Robin Y., 29 HARV. C.R.-C.L. L. REv. 559 (1994).

80. See Hollandsworth, supra note 72.

81. See generally Martha A. Field, Surrogate Motherhood: The Legal AND Human Issues (2d ed. 1990); SCOTT B. RAE, THE ETHICS OF COMMERCIAL SurRogate MotherhoOd: Brave New Familes? (1994); SurRogate MothERHOOD: POLITICS AND PRIVACY (Larry Gostin ed., 1990); Randy Frances Kandel, Which Came First: The Mother or the Egg?, A Kinship Solution to Gestational Surrogacy, 47 RutGERS L. REV. 165 (1994).

82. See Hollandsworth, supra note 72 , at 201-07 (providing a helpful review of state statutes).

83. Many states have adopted some version of the Uniform Status of Children of Assisted Conception Act, which restricts surrogacy agreements to married couples. See, e.g., VA. CODE ANN. $\S 20-159$ (1996). Arkansas is apparently the only state that ex- 
ment, and, when they are able to do so, they would still have to overcome the adoption problems that lesbian couples face when both partners seek to be recognized as the legal parents of the child born to one of them. A few gay male couples have successfully negotiated the difficulties, with both partners ending up accepted by the state as the child's legal parents, ${ }^{84}$ but couples in other states would presumably founder on formal and informal policies barring adoptions by unmarried couples and homosexual persons. The issues surrounding surrogacy are complex, but, whatever their resolution, gay male couples need access to whatever scheme is made available to opposite-sex married couples.

\section{When Neither Partner is the Biological Parent: Adoption and Foster Care}

Gay men and lesbians also wish to adopt or serve as foster parents for children who are not the biological child of either partner. Today, a few states prohibit lesbians and gay men from adopting under any circumstances and a few others prohibit them from serving as foster parents. ${ }^{85}$ Most other states make adoption or foster care very difficult in practice for persons who are openly gay or lesbian ${ }^{86}$ Gay people are not alone in encountering difficulties in adoption. Single heterosexual individuals are also disfavored in practice almost everywhere. ${ }^{87}$ When single persons, gay or heterosexual, are permitted to adopt, they are often offered only the most hard-to-place children, children who are older and have had multiple foster placements, or children with multiple handicaps. ${ }^{88}$

By contrast, while procedures for adoption and foster care vary widely across the country, it is the case everywhere that, whatever the procedure, the married heterosexual couple stands highest in the hierarchy of preferred units for placement of a child. ${ }^{89}$ The status that is ac-

plicitly permits an unmarried man to enter into a surrogacy arrangement. See ARK. CoDE ANN. § 9-10-201 (Michie 1996); Hollandsworth, supra note 72, at 205.

84. See Hollandsworth, supra note 72 , at 200.

85. See supra note 72 for state laws relating to adoption. New Hampshire by statute prohibits gay men and lesbians from serving as foster parents. See Joseph Evall, Sexual Orientation and Adoptive Matching, 25 FAM. L.Q. 347, 352-54 (1991); Developments in the Law - Sexual Orientation and the Law, 102 HARV. L. REV. 1508, 1643 (1989).

86. See Wendell Ricketts \& Roberta Achtenberg, The Adoptive and Foster Gay and Lesbian Parent, in GAY AND LeSBIAN PARENTS 89-111 (Frederick Bozett ed., 1987).

87. See Elizabeth Bartholet, FAMILy Bonds: ADOPTION AND tHE POLITICS OF PARENTING 70-72 (1993).

88. See id.; see also Hollandsworth, supra note 72 , at 197 n.54.

89. BARTHOLET, supra note 87 , at 70 . 
corded to married opposite-sex couples today would provide fully adequate legal protection for the interests of gay male and lesbian couples and for the children they would raise. The increased opportunity to adopt that same-sex couples would enjoy if allowed to marry would arise less from particular formal rules than from the effects on judges and agencies of the legislature's blessing, for in many places it is not legal prohibitions that hold judges back from placing children with gay individuals or couples, but rather a belief that gay people are not socially acceptable caretakers of children.

The troubling question for those disposed toward legal same-sex marriage is not whether the adoption opportunities available to married couples today would help lesbian and gay couples enough. It is whether they would help them too much. Some might claim that no rational basis exists for preferring married couples over single persons or over unmarried couples. ${ }^{90} \mathrm{I}$ believe that both preferences are at least rational, even if not fully sensible. ${ }^{11}$ But, even if the justification is tenuous, gay couples should not resist marriage simply because others remain discriminated against in this context. The answer lies in working to change over time the inappropriate limitations on others' access to adoption. Permitting gay and lesbian couples to adopt is likely to advance rather than hinder movements for single-parent adoption, because successful adoptions by lesbian and gay couples are likely to help corrode the myth that it takes two persons of opposite sexes as parent figures to raise a child adequately.

\section{Laws Regulating the Economic Relationship of Couples or Between the Couple and the State}

A considerable majority of the laws that provide for differing treatment for married persons deal with the married couple as an economic unit. They build on beliefs or guesses about the economic relationships

90. As to the discrimination in adoption against single persons, see Jennifer Jaff, Wedding Bell Blues: The Position of Unmarried People in American Law, 30 ARIz. L. REV. 207, 216-17 (1988).

91. The justification for preferring couples over single persons runs as follows: first, that children will be better off in general when able to rely on two caretakers and two sources of support and, second, that even if there is no evidence that children adopted by single parents fare less well than children adopted by couples, a preference for couples, in places with limited numbers of available children, creates the likelihood that each adopted child brings pleasure to two adults. As to the preference for married couples over other pairs of persons who come forward to adopt, there may be no rational reason to prefer married couples to couples who have entered some other formal relationship like a domestic partnership, but the state does have a basis for preferring as adoptive parents couples who have indicated a commitment to remain together. 
that married persons actually have and on prescriptive views about what those relationships ought to be. They assume that married persons differ from most single persons, including most single persons who share a residence with another person, in one or more of the following ways: the married partners will live more cheaply together than they would if they lived apart (that is, that there are routine economies of scale); the two will pool most or all of their current financial resources; the two will make decisions about the expenditure of these resources in a manner not solely determined by which party's labors produced the resource; the two will often engage in divisions of labor for their mutual benefit; and one partner, typically the woman, will often become economically dependent on the other.

To the extent that these laws have an empirical foundation, it is unclear whether the images of opposite-sex relationships that lie behind them will fit the circumstances of the sorts of gay male and lesbian couples who would marry under a change in the law. No adequate research exists about the current behavior or expectations of lesbian and gay couples regarding the economic dimensions of their relationships, and we cannot know, of course, what sorts of couples would choose to marry in the future. ${ }^{92}$ What evidence there is suggests that most lesbian and gay couples in long-term relationships believe in pooling resources and practice it today, ${ }^{93}$ and that pooling is particularly common among those who engage in ceremonies of commitment. ${ }^{94}$ The evidence leaves open the strong possibility, however, that long-term same-sex couples generally keep more of their resources separate than married oppositesex couples do - that more are cost "splitters" rather than

92. Not surprisingly, none of the studies of gay and lesbian couples, including the few that examine the manner in which they handle finances, differentiates between those couples who would legally marry if they could and those who, like many heterosexual couples, would choose to remain single even if marriage were legally available.

93. The best available information about the economic behavior of gay and lesbian couples comes from Blumstein and Schwartz's pioneer study from the early 1980s of the handling of money by American couples. See BLuMSTEIN \& SCHWARTZ, supra note 51, at 94-111. This study included substantial but nonrandom samples of married and unmarried opposite-sex couples and of gay male and lesbian couples. The authors found that the great majority of married opposite-sex couples expected and favored the pooling of income and resources. Gay men and lesbians in couples had more diverse attitudes, with a significant minority of both women and men opposing pooling. Still, for those in relationships that had lasted more than two years, the proportion who favored pooling substantiaily exceeded the proportion who opposed it. Blumstein's samples of same-sex couples did not differentiate between those who would and would not have married if legal marriage had been available.

94. See Lesbian AND GAy MARRIAGE, supra note 5, at $115,127,145,153,163$, 208 (recorded interviews). 
"poolers." 95 It is also probable that, if permitted to marry, fewer persons in same-sex marriages would become economically dependent on their spouses than occurs among women in opposite-sex marriages today.

Rather than attempt to generalize in the abstract about the similarities and differences of opposite- and same-sex couples in the handling of the financial aspects of their relationships, I will consider the probable fit of various laws with the conditions of gay and lesbian couples as each sort of regulation is considered. The review that follows divides the many financial regulations that treat married persons differently than single persons into three rough sorts - those that fix the relationship between married persons and the state, those that fix the economic relationship between the two married persons themselves, and those that fix the relationship between the two married persons and private third persons - because these sorts of regulations typically serve quite different ends. Even with this crude division, the widely varying laws of the fifty states hamper any attempt to characterize the legal incidents of marriage, for these laws are neither identical to one another nor internally consistent within states. Still, there is a certain coherence to it all.

\section{The Regulation of the Financial Relationship Between Married Persons and the State}

Tax laws and laws pertaining to government benefits commonly treat married persons in a distinctive manner by regarding them for most purposes as a single economic unit. These laws have a rough logic to support them but sometimes produce unintended behavioral effects.

Consider some central examples. Federal and state income tax laws create a system of joint returns for married couples that treats the couple as a single economic entity. ${ }^{96}$ Under these provisions, when only one spouse earns any income, the total tax liability for the couple will be less than it would be if the income-earning spouse filed as a single person, a result that may be thought justified because two people are living on the single earner's income. On the other hand, when both spouses work and each earns even a fairly moderate income, their total

95. Jane Bryant Quinn observes that not all married heterosexual couples pool their resources. She cleverly observes two patterns for handling income and expenses even within married couples: "splitters" who keep their own separate accounts, and "poolers" who put everything into a common pot. Over time, she says, if the marriage goes well, "splitters usually tum into spoolers, splitting some, pooling some, and growing less antsy about who pays for what." JANE BRYANT QUINN, MAKING THE MOST OF YOUR MONEY 81 (1991). She does not rely on statistics.

96. See I.R.C. § 1(a) (1994). 
tax liability will often be higher than it would have been if each had filed as a single person, a result that may again be thought justified because, by pooling incomes, they can live together more inexpensively than two single persons living separately. ${ }^{97}$ In many situations, these two sets of rules produce wholly justifiable outcomes, but their paradoxical impact in practice is that many working men and women maximize their incomes by living together but not marrying, each filing a separate return, even though they might otherwise prefer to marry. ${ }^{98}$ The same rules also discourage some married women from seeking employment outside the home, because they conclude that the marginal tax rate on any earnings they produced would be so high as to make their economic contribution trivial. ${ }^{99}$

Similar rough justifications and undesired effects characterize the rules that apply when low-income married persons who are aged, blind, or disabled apply for federal welfare benefits under the program of Supplemental Security Income (SSI). If a married couple apply together, their grant will be lower than it would be if they were treated as two individuals applying separately. ${ }^{100}$ Similarly, if only one member of the couple applies, the income of the applicant's spouse will be assumed to be available to the applicant and will be taken into account in determining both the applicant's eligibility for the benefit and the size of the grant. ${ }^{101}$ Much the same rules of income attribution apply when a married person seeks a government-backed educational loan. ${ }^{102}$ For couples who in fact pool their income and resources, these government benefit

97. For example, two single individuals living together who each earn $\$ 30,000$ would pay $\$ 1248$ less in total federal income taxes than two married individuals who earn the same amounts and filed a joint return. See Jonathan B. Forman, What Can Be Done About Marriage Penalties?, 30 FAM. L.Q. 1, 5 (1996). Similar differences apply to low-income earners who qualify for the Earned Income Tax Credit. See Anne L. Alstott, The Earned Income Tax Credit and the Limitations of Tax-Based Welfare Reform, 108 HARV. L. REV. 533, 559-64 (1995).

98. A fine recent critique can be found in Edward J. McCaffery, Taxation and the Family: A Fresh Look at Behavioral Gender Biases in the Code, 40 UCLA L. REV. 983 (1993) [hereinafter McCaffery, Taxation and the Family]. See also Edward J. McCaffery, Slouching Towards Equality: Gender Discrimination, Market Efficiency, and Social Change, 103 YALE L.J. 595, 617-19 (1993) [hereinafter McCaffery, Slouching Towards Equality].

99. See sources cited supra note 98.

100. See 42 U.S.C. $\S 1382$ (b) (1994).

101. 42 U.S.C. $\S 1382 \mathrm{c}(\mathrm{f})(1)(1994)$. An unusual section in the statute establishing the program of Supplemental Security Income provides that if a man and woman "hold themselves out as married," they will be treated for purposes of the SSI program as if they were married. 42 U.S.C. $\$ 1382 c(d)(2)$ (1994). Federal laws recognize the unmarried couple only when those laws work to the couple's financial disadvantage.

102. See 20 U.S.C. $§ 1087 \mathrm{pp}, 1087 \mathrm{nn}(\mathrm{b})(1)(\mathrm{A})$ (1994). 
rules make sense, but they can impose hardships when the rules attribute more income as available than the spouse can comfortably contribute $^{103}$ and can sometimes deter couples from marrying who otherwise would.

Government taxing and benefit regulations of other sorts also build on the expectation that married couples will share resources and recognize that one spouse is often economically dependent on the other. Some of these programs, fortunately, avoid the undesired behavioral incentives we have just discussed. When a long-employed worker retires with a spouse who has been a homemaker and has not worked in the labor force long enough to be entitled to full Social Security benefits in her own right, the nonworking spouse, if over sixty-two, is entitled to benefits through the worker. ${ }^{104}$ Similarly, when a long-employed worker dies, Social Security benefits will typically be available for a surviving spouse over sixty who is not entitled to full benefits through her own contributions as an employee. ${ }^{105}$

Gift and estate taxes also reflect a view of the married couple as a single economic unit in which dependencies arise. When a well-heeled spouse transfers property to the other spouse during the marriage, the transfer is not subject to the federal gift tax that would apply to gifts to others, including the donor's children. ${ }^{106}$ When appreciated assets held in the name of one spouse are transferred at divorce to the other spouse, no capital gains tax or gift tax is due at the time of the transfer. ${ }^{107}$ And, when a spouse dies, bequests to the other spouse are not taxed under federal estate tax laws. ${ }^{108}$ Public and private employers further recognize the economic interdependency of spouses by making health care benefits available to their employees' spouses, and, just as federal and state income tax laws exempt from taxation the value of a worker's own employer-provided health care benefits, so too these same laws exempt from taxation the value of the benefits for the worker's spouse. ${ }^{109}$

103. See Paul Drizner, Comment, Medicaid's Unhealthy Side Effect: The Financial Burdens on At-Home Spouses of Institutionalized Recipients, 18 LOY. U. CH. L.J. 1031, 1036-47 (1987).

104. 42 U.S.C. § 402(b)-(c). See U.S. Social SECURITY ADMINISTRATION, So. CIAL SECURITY HANDBOOK, $\$ 305$ (12th ed. 1995). In much the same manner, a divorced spouse not fully covered through her own employment will be covered through her former spouse on reaching the requisite age. See id.

105. See id. $\$ 401$.

106. See I.R.C. $\S \S 1041,2523$ (1996); see also Patricia A. Cain, Same-Sex Couples and the Federal Tax Laws, 1 L. \& Sexuality 97, 123-29 (1991).

107. I.R.C. $\$ 1041$ (a)-(c) (1996).

108. See I.R.C. $\S 2056$ (1996).

109. I.R.C. $\$ \S 105,213(1996)$. 
Gay and lesbian couples are subject to none of these rules, neither the benefits nor the burdens. ${ }^{110}$ No joint return. No attributed income. No exemption from gift or estate taxes. Even when employers provide health benefits to both married employees and to employees with a same-sex domestic partner, only the married employees obtain the benefit of the tax exemption for the value of their partners' health coverage; the employee with a same-sex partner must report the value of the benefit to his partner as income and pay taxes on it.

Would gay and lesbian couples be advantaged by being treated like heterosexual married couples across this range of state and federal legal consequences? They would be subject to the same unfortunate behavioral incentives that these rules create today for opposite-sex couples. ${ }^{111}$ A gay man with HIV on Medicaid, for example, might choose not to marry on learning that, if he did, he would cease to be eligible for benefits even though his partner and he did not actually earn enough to pay the couple's medical bills. Indeed, it is possible that an even higher proportion of gay male and lesbian couples would be economically disadvantaged by the application of the current tax laws than are married opposite-sex couples. The only couples who consistently benefit from the current laws are those in which only one partner works in the labor force, and, taxes aside, both partners prefer this arrangement. ${ }^{12}$ Given enduring sex-ascribed roles, the employment of only one partner is likely to be the situation more often in opposite-sex than in same-sex couples. Moreover, the premise of many of the current rules is that married couples actually share in the control of resources and expenditures. ${ }^{113}$ When that premise fails, it is doubtful whether the burdens of the joint return should be imposed. Some observers have raised doubts about the actual degree of sharing of control in most heterosexual married couples, ${ }^{114}$ and it is quite possible that an even higher proportion of gay men and lesbians who would marry would be persons who in their day-to-day lives would share only some of their income.

On the other hand, remember that not all tax and welfare rules work to the harm of gay couples who would marry. In some couples, only one partner would work in the labor force, and for them the benefits of health coverage and the joint tax return might be substantial. In others, both partners would work, but only one with a job with medical

110. See Cain, supra note 106.

111. See supra note 98 and accompanying text.

112. See supra note 98 and accompanying text.

113. See Marjorie E. Kornhauser, Love, Money and the IRS: Family, IncomeSharing, and the Joint Income-Tax Return, 45 HASTINGs L.J. 63, 73-80 (1993).

114. See id. 
benefits. For them, the value of tax-exempt benefits through the partner with coverage could be considerable. And for those at the highest end of the income scale, the benefits of the estate and gift tax exemptions might more than offset the disadvantages of a joint return.

Moreover, in actual practice, even for the couple in which both partners work and both earn significant incomes, the income tax and other rules may in actual practice less frequently cause behaviors experienced as painful by the parties. When neither partner in a couple considers himself or herself the "secondary" worker - when both partners, that is, have strong ties to the labor force - then, while the perversities of the tax laws may affect some decisions to marry, they are less likely to lead either partner to drop out of the labor force or feel economically useless in a manner that he or she resents or later comes to regret. And, viewed from another perspective, the opportunity for legal marriage, at the very least, provides a choice to opposite-sex couples whether to marry or not, a choice from which lesbian and gay couples could benefit for the same sorts of reasons.

\section{The Regulation of the Financial Relationship Between Married Partners}

In the United States today, states employ either of two broad schemes of regulation to define the economic relationship between married partners. Nine states (mostly in the West and Southwest) employ "community property" regimes,"15 under which, to oversimplify, the spouses own separately whatever they bring into the marriage or receive by gift or bequest during the marriage and own jointly any other assets either of them acquires during the marriage, including all assets acquired from their labors. ${ }^{116}$ The earnings of each partner are owned jointly by the pair. ${ }^{117}$ In the remaining states, called "common law states," again to oversimplify, the spouses own separately whatever they acquire in their separate names and jointly whatever they buy in both names or whatever one by deliberate act puts into joint control. ${ }^{118}$ Their earnings are their own. These differences in law sound significant

115. See Elrod \& Walker, supra note 49, at 695 (table). The states are Arizona, California, Idaho, Louisiana, Nevada, New Mexico, Texas, Washington, and Wisconsin.

116. See Roger A. Cunningham et al., The Law of Property $\$ 5.14$, at 232-33 (2d ed. 1993); W.S. MCClanahan, COMMUnity Property IN THE UNited STATES $\S \S 1: 6,1: 8(1982)$.

117. Though "owned" jointly, "control" over the earnings may lie initially with the eamer. For example, a paycheck made out to an employee need not be endorsed by the spouse before being cashed.

118. See CunNingham et al., supra note $116, \S 5.15$; McClanahan, supra note $116, \S 1: 07$ (comparing common law and community property states). 
and may affect many married persons' perception of the nature of their relationship, ${ }^{119}$ but it is probable that personal characteristics and social conventions linked to gender have greater impact than formal legal rules on the way that assets are controlled by married persons who live together. ${ }^{120}$

The rules of property do, however, become crucial at the point of divorce, for all states impose rules of distribution that have significant impact on the separate spouses' financial well-being. State divorce laws differ widely in their structures and in their details, but commonly produce similar outcomes.

In community property states, each divorcing spouse is entitled to one-half of the property acquired during the marriage. In some states judges may deviate from this division in extraordinary circumstances. ${ }^{121}$ The remaining states have adopted more flexible schemes of property division generally called "equitable distribution." In these states, courts are permitted to ignore the rules of separate ownership and divide all property acquired during the marriage in an equitable manner. Most statutes list factors for judges to take into account, ${ }^{122}$ including, for example, each spouse's contribution to the acquisition of an asset and the economic position of each spouse at the point of separation. Some states also permit judges to take "fault" into account, and to reach into assets acquired before the marriage or received by gift or inheritance. ${ }^{123}$ In practice in many equitable distribution states, lawyers for divorcing persons begin negotiations with an assumption of a division closely similar to the division imposed in community property states: in the absence of special circumstances, the couple will divide equally all assets acquired by either during the marriage. ${ }^{124}$ And in practice in many community property and equitable distribution states, the actual division of

119. Lawrence Waggoner believes that the two sets of rules serve to "reinforce the profoundly different symbolical and psychological feelings within the ongoing marriage." See Waggoner, supra note 29, at 27.

120. See generally BLUMSTEIN \& SCHWARTZ, supra note 51 (describing the personal and social characteristics motivating heterosexual relationships and comparing them to those motivating homosexual and lesbian relationships).

121. See Elrod \& Walker, supra note 49 , at 723-25.

122. See id. 716-21; UNIF. MARRIAGE \& DIVORCE ACT $\$ 307$, 9A U.L.A. 238 (1987).

123. See Elrod \& Walker, supra note 49 , at 725-28.

124. See, e.g., Grace Blumberg, Marital Property Treatment of Pensions, Disability Pay, Workers' Compensation and Other Wage Substitutes: An Insurance or Replacement Analysis, 33 UCLA L. REv. 1250, 1251 (1986); Elizabeth A. Cheadle, The Development of Sharing Principles in Common Law Marital Property States, 28 UCLA L. REV. 1269 (1981). Some common law states have translated this beginning point into a formal statutory presumption. See, e.g., OHIo Rev. CoDE ANN. § 3105.171(A) (Anderson Supp. 1995). 
property negotiated by parties often deviates from a fifty-fifty distribution in ways that have little to do with formal legal rules. ${ }^{125}$

What is critical for our purposes is that at the point of divorce, under either regime, married persons encounter formal systems of forced allocation of assets that treat married persons as economic partners while they were together. Thus, as a single important example, for many long-married couples today the largest single asset owned by either is a pension account accumulated in the name of one of them. In both community property and common law states, that part of the pension assets attributable to the period of the marriage will be subject to division between the partners. ${ }^{126}$

State law also responds at divorce to imbalances in earning capacity between spouses, imbalances that have often been magnified during the "partnership." It does so in common law states by allowing judges to consider the disparate financial positions of the parties in the distribution of property. ${ }^{127}$ Many states have also devised doctrines that permit courts to compensate a spouse in some manner for helping to increase the human capital of the other partner, most commonly by bearing the costs of putting the partner through professional school.128 In addition, both community property states and common law states permit courts to award periodic payments, called alimony or maintenance, for the support of a spouse unable adequately to provide for herself or himself after separation. ${ }^{129}$ Today alimony is awarded less frequently and for shorter durations than in the past. ${ }^{130}$ It nonetheless remains common after long-term marriages in which one party has high

125. See, e.g., Marsha Garrison, Good Intentions Gone Awry: The Impact of New York's Equitable Distribution Law on Divorce Outcomes, 57 BroOK. L. Rev. 621 (1991).

126. See Ira Ellman et al., FamLy Law 253-57 (1991).

127. See UNIF. MARRIAGE \& DivorCE ACT $\S 307$ (a), 9A U.L.A. 239 (1987), adopted in many states.

128. See Linda D. Elrod \& Robert G. Spector, A Review of the Year in Family Law, 29 FAM. L.Q. 741, 774 tbl. 5 (1996). A few states treat the professional degree earned during the marriage as property subject to equitable division. See, e.g., O'Brien v. O'Brien, 489 N.E.2d 712 (N.Y. 1985). In some others, compensatory payments much like alimony may be ordered by the court. See, e.g., Mahoney v. Mahoney, 453 A.2d 527 (N.J. 1982). In California, a community property state, special legislation permits a court to order a divorcing spouse to reimburse the other spouse for the costs of tuition and education. See CAL. FAM. CODE § 2641 (West 1994).

129. See Elrod \& Spector, supra note 128, at 770 tbl. 1; 2 CLARK, supra note 18, 220-334.

130. See Leonore Weitzman, The Divorce Revolution: THE UneXPECTED SOCIAL AND ECONOMIC CONSEQUENCES FOR WOMEN AND CHILDREN IN AMERICA 33 (1985). 
earnings and the other party, almost always the wife, has been a longterm homemaker. ${ }^{131}$

Death is another occasion when the law imposes financial obligations because of marriage. Under the laws of nearly all states, a married person cannot unilaterally prevent his spouse from inheriting part of his assets. Thus, when a married person dies with a will and the will fails to provide for the surviving spouse, the laws of nearly all common law states permit the surviving spouse to claim a "forced" or "elective" share of the estate, commonly one-third or one-half. ${ }^{132}$ Much the same result is reached in long-term marriages in community property states because, no matter what one spouse considers to be her separate property and attempts to bequeath by will to others, one-half of the assets acquired by the couple during the marriage will be considered the property of the other spouse at death. ${ }^{133}$

Thus at both divorce and death, states impose on married couples a prescriptive view of the appropriate financial relationship between them. Most states now permit couples, at the point of marriage or during the marriage, to contract for a different arrangement on death or divorce than the law would otherwise impose, though also placing some limits to ensure that the decision to contract was "voluntary" and "informed." 134

131. See Ann L. Estin, Maintenance, Alimony and the Rehabilitation of Family Care, 71 N.C. L. REv. 721, 745-46 (1993). For heterosexual married couples today in which the wife has not been in the labor force, the alimony and property division rules facilitate at least modestly the division of labor within couples - one developing material wealth, one providing care for the family or pursuing nonwealthgaining activities. See Ira M. Ellman, The Theory of Alimony, 77 CAL. L. REV. 1 (1989); but see Jana B. Singer, Alimony and Efficiency: The Gendered Costs and Benefits of the Economic Justification for Alimony, 82 Geo. L.J. 2423 (1994).

132. See Ralph C. Brashier, Disinheritance and the Modern Family, 45 CASE W. RES. L. REv. 83, 99-104 (1994); Lawrence Waggoner, Spousal Rights in Our MultipleMarriage Society: The Revised Uniform Probate Code, 26 ReAL Prop., Probate \& TR. J. 683, 720 (1994); see also UNIF. PROB. CODE $§ 2-102,8$ U.L.A. 59 (1982) (dividing the marital assets on a 50-50 basis).

133. See Brashier, supra note 132, at 97 . The elective share rule can produce anomalous results in common law states in some cases in which a person dies shortly after marriage to a person who already has substantial assets of his or her own.

134. See Ellman ET AL., supra note 126, at 662-87; Marjorie M. Shultz, Contractual Ordering of Marriage: A New Model for State Policy, 70 CAL. L. REv. 204, 280-88 (1982). Eighteen states have adopted the Uniform Premarital Agreement Act. See Note, Till Divorce Do Us Part: The Validity of Antenuptial Agreements in Michigan, 38 WAYNE L. REV. 1919, 1921 n.3 (1992). Such agreements are apparently fairly common among wealthy persons who have children and who remarry late in life and who want to preserve for their children the assets they have acquired up to that point in their lives. 
How, by comparison, does the law treat the income and assets of single persons with a long-term partner? Very differently indeed. In both community property and common law states, the earnings of an unmarried person and the resources bought with those earnings are entirely the property of the earner. Moreover, in no state today, does the state impose on the estate of an unmarried person a forced share for a surviving partner. ${ }^{135}$ An unmarried person can leave her money to whomever she pleases, no matter how long a relationship she may have had with a partner.

The rules relating to the breakup of unmarried couples vary widely among the states. Until the last thirty years or so, courts in nearly all states refused to intervene at all, even when the parties had agreed to share assets, on the ground that the cohabiting relationship itself was immoral. ${ }^{136}$ A few states still retain this approach. ${ }^{137}$ In most states, however, the law has changed, responding to the huge growth in the numbers of unmarried opposite-sex couples living together and to the changed social perception of the acceptability of such cohabitation..$^{138}$ Courts will enforce express agreements between unmarried persons to support each other or to divide property titled in the other's name. ${ }^{139}$ Some of the cases have involved same-sex couples. ${ }^{140}$

A few states have gone further than the enforcement of agreements, coming closer to imposing a marital regime. Some will enforce "implied contracts," the contents of which courts infer not from words of agreement between the partners but from the partners' conduct and which may in fact not reflect any actual agreement between the parties. ${ }^{141}$ In a few more states, judges will, at the request of a separating long-term unmarried partner, simply impose a property division that seems "just," even in the absence of any express or implied agreement

135. Waggoner, supra note 29 , at $62-63$.

136. See, e.g., Wallace v. Rappleye, 103 Ill. 229, 249 (1882).

137. See, e.g., Hewitt v. Hewitt, 394 N.E.2d 1204 (Ill. 1979).

138. On the demographic changes, see Arlen Thornton, Cohabitation and Marriage in the 1980s, 25 DEMOGRAPHY 497 (1988); Waggoner, supra note 29, at 63.

139. See Marvin v. Marvin, 557 P.2d 106 (Cal. 1976) (holding that courts should enforce contracts between unmarried partners); Morone v. Morone, 413 N.E.2d 1154 (N.Y. 1980); see also Ellen Kandoian, Cohabitation, Common Law Marriage, and the Possibility of a Shared Moral Life, 75 GEO. L.J. 1829 (1987).

140. Only a few states have appellate decisions on the question whether such contracts will be honored for same-sex couples. See, e.g., Jones v. Daly, 176 Cal. Rptr. 130 (1981).

141. In the Marvin case, the California Supreme Court invited enforcing implied contracts and other traditional equitable remedies. See Marvin, 557 P.2d at 122-23. In Morone, the New York Court of Appeals held that its courts would enforce express but not implied contracts. See Morone, 413 N.E.2d at 1156. 
between the parties. ${ }^{142}$ In most states, however, unmarried partners still have no state-prescribed obligations to each other that apply in the absence of agreement. Each can walk away taking whatever is titled in his or her name.

At first blush, the rules currently applied in most states to the unmarried may seem to most gay men and lesbians preferable to the rules of forced sharing imposed on married people. Most states, as just described, impose on unmarried couples only what the couple itself has agreed to. Such a regime may well appeal to couples who are suspicious of the state and couples in which neither partner is economically dependent on the other. Many individuals in couples in which both partners are working would reject the notion that all their resources are joint or that they have continuing responsibilities for the welfare of the other if they break up. ${ }^{143}$ Many would, for example, probably consider their pensions to be separate property, even though acquired during the relationship. Many would find notions of alimony offensive. And, even if they saw themselves as having some continuing responsibilities, many would reject the notion of the state, through its judges, having the power to apportion fault or responsibility between them under the discretionary guidelines found in common law states.

All this is true, yet I think that the rules regarding the financial aspects of divorce now in place for married couples would serve lesbian and gay male couples reasonably well. In the first place, the property rules of divorce are given life as part of a larger set of procedures governing divorce proceedings, procedures that encourage, or force, couples to wind up their financial relationship prior to moving on to another relationship. Many people would acknowledge (at least ex ante) the value of having some sort of regularized process for dividing property, without regard to the particular rules. In the second place, the rules regarding the division of property for married people are, to an increasing extent, subject to alteration by the agreement of the parties. Before or during marriage, the parties may contract for different outcomes between them that will be honored by courts if voluntarily entered. ${ }^{144}$ So

142. See Shuraleff v. Donnelly, 817 P.2d 764 (Ore. Ct. App. 1991); Worden v. Worden, 676 P.2d 1037 (Wash. Ct. App. 1984). Even in these cases, the courts have refused to adopt as a general rule a principle of equal division such as they impose on divorcing couples.

143. See BlumsteIn \& SchwartZ, supra note 51.

144. See Grace G. Blumberg, New Models of Marriage and Divorce, in CONTEMporary Marriage: Comparative Perspectives on a Changing Institution 349, 354 (Kingsley Davis ed., 1985). 
seen, the rules of marriage operate as a default regime for couples who marry and do not choose a different scheme for themselves.

Of course, just as only a small proportion of opposite-sex married couples enter agreements today to vary from the rules otherwise imposed at divorce, so it is probable that few gay male and lesbian couples would do so in the future. My own belief, however, is that a default rule of imposed sharing is preferable for gay male and lesbian couples to the default rule of separate property and no continuing obligations that now exists for unmarried couples. As a starting point, a great many - though by no means all - gay men and lesbians who would choose to marry would engage voluntarily in the substantial pooling of resources. ${ }^{145}$ They would probably feel comfortable with the notion that assets that they acquired and used during the relationship furniture or appliances, for example - belonged to them jointly even though one of them paid the bill on her separate account. Conversely, those gay and lesbian individuals who would wish to marry but care a great deal about financial independence - those who, for example, would wish to be certain to keep their pensions separate or avoid the payment of alimony - would probably be of higher than average economic status and in a better position to know about and to take the initiative to contract out of the default rules than are those who value sharing. ${ }^{146}$

And, finally, as between the two sets of default rules, the moral claims for independence and separate ownership have their own weaknesses. Some may look at the world of forced sharing and alimony, remember a time when married women could own nothing in their own name, and wish to reject any reminders of the dependence of women on their husbands. ${ }^{147}$ But the world of independence has its own poisoned roots. Independence in law means that the person with legal title wins, and title, standing alone, bears little necessary relation to the efforts that lie behind the generation of the asset or to the moral implications of a long-shared life.

145. See supra note 94 and accompanying text.

146. In American Couples, Blumstein and Schwartz do not indicate the correlation between willingness to pool and income level, but they do report that, among gay men, when one partner has much more income than the other, he typically asserts considerable control over the expenditure of income and shares decisionmaking less. See BLUMSTEIN \& SCHWARTZ, supra note 51, at 105, 59-60. These high-earning men seem in the best position to protect themselves by insisting on agreements about keeping assets separate.

147. Cf. Herma Hill Kaye, Equality and Difference: A Perspective on No-Fault Divorce and Its Aftermath, 56 U. CIN. L. REv. 1 (1987). 
Taken together, these considerations even support the claim that the default property rules for marriage will not merely serve most gay and lesbian couples reasonably well but will, in general, serve gay and lesbian couples who choose to marry better than they serve opposite-sex married couples today. As others have pointed out, the rules of sharing for married couples today still typically leave most women in depleted financial circumstances after divorce and cause particular harm to those who have cared for children. ${ }^{148}$ The equitable distribution and community property rules do force a sharing of assets acquired during marriage, but women often do not receive even half of the available assets. ${ }^{149}$ Moreover, men commonly leave marriages with enhanced earning capacity, while women, who already earn much less, often find their capacity to generate income impaired. ${ }^{150}$ Alimony, when ordered at all to redress the imbalance, is typically too small to bring women anywhere near their prior standard of living. ${ }^{151}$ It also proves difficult to enforce.

Gay men and lesbians compelled on separation to share assets will be hurt less frequently when the law's promise of sharing fails to produce economic parity between the partners. Because the members of such couples are always of the same sex they more often earn similar incomes and are less likely to have gender-assigned expectations of divided responsibilities for income production during the relationship.

Despite my claims that gay men and lesbians will in general be served decently by the financial rules of marriage, some reasons for pause still exist. In the common law states especially, the process of resolving disputes over financial matters brings married couples under the authority of judges with broad discretion. How judges, most of them heterosexual, will respond to gay and lesbian couples who come before them is hard to predict. Even if they try to comprehend and apply the norms accepted by the same-sex couple, they may be unable to do so. How will they respond when a gay man has been financially dependent on an older partner by tacit agreement of the partners? Here lingering distaste for homosexual persons may mix with a general bias against

148. Martha A. Fineman, The Illusion of Equality: The Rhetoric AND REALITY OF DIVORCE REFORM 4 (1992); June Carbone, Equality and Difference: Reclaiming Motherhood as a Central Focus of Family Law, 17 L. \& Soc. INQUIRY 471 (1992).

149. See Garrison, supra note 125 , at 671 .

150. See FinEMAN, supra note 148, at 36-37; see also DAvid Chambers, MAKING FATHERS PAY 37-68 (1979).

151. For a review of views about the functions of alimony and the social position of women, see June Carbone \& Margaret Brinig, Rethinking Marriage: Feminist Ideology, Economic Change, and Divorce Reform, 65 TuL. L. REv. 953, 987-1004 (1991). 
the financially dependent male. ${ }^{152}$ How will judges respond to a samesex couple in which one but not both have had frequent sexual partners outside the couple? ${ }^{153}$ I have no easy answer to these worries. The problem, however, for any couple concerned about judicial discretion can be ameliorated or avoided by contractual agreement about obligations or by agreement to mediate or arbitrate using a third party whose sensibilities they trust. But many couples will surely fail to enter into such agreements and one or both of them ultimately will feel abused by the judicial system.

\section{The Regulation of the Relationship Between the Married Couple and Third Persons}

Just as states create rules defining the state's relationship with married persons and of married persons' relationships with each other, so also, in a narrower range of circumstances, states prescribe rules for the relationship between married persons and private third parties. Most such private relationships are left to private ordering: a married person can negotiate to borrow money on her own or to borrow with her spouse (or with anyone else for that matter); employers and employees negotiate over whether or not spouses will be included in various benefits. But a few protections and obligations are not left solely to the private sphere, and the rules that do exist again build upon notions of the married couple as a mutually interdependent economic unit.

A handful of states, for example, now require employers over a certain size to provide access to health insurance to the otherwise uninsured spouses of employees. ${ }^{154}$ Similarly, in a quite different context, all states provide for a spouse to recover in a wrongful death action for economic losses when a third party has caused the death of the other spouse by negligence or an unjustified deliberate act. ${ }^{155}$ These protections for spouses are matched by at least one legal burden: most states impose on spouses an obligation to pay for "necessaries," such as

152. Cf. Jones v. Daly, $176 \mathrm{Cal}$. Rptr. 130 (1981) (concluding without adequate foundation that a relationship between two men, one of whom was old and rich and the other young and economically dependant, rested primarily on sex as the consideration).

153. In many states, judges may consider marital "fault" in dividing property or awarding alimony. See 2 CLARK, supra note $18, \S 16.3$, at $194-96$ (property); id. $\S 17.5$, at 267-69 (alimony); Elrod \& Walker, supra note 49, at 534. Judges rarely get the opportunity to exercise their discretion because, in the overwhelming majority of cases, parties settle before a hearing, but the prospect that a judge will take fault into account can affect the bargaining process between partners.

154. See, e.g., HAw. REv. STAT. \$§ 87-4, 393-7, 393-21 (1993).

155. 2 StuARt M. SPEISER ET AL., ReCOVERY FOR WRONGFul DeATH AND INJURY $§ 10.2$ (3d ed. 1992). 
emergency medical care, provided by third parties to the other spouse. ${ }^{156}$ More broadly, in most community property states, a creditor can collect out a married couple's community property for a debt contracted by one of the spouses, without regard to the contribution of that spouse to the community property. ${ }^{157}$

None of these protections and burdens applies to unmarried couples. ${ }^{158}$ Yet, in differing degrees, they probably justly fit the circumstances of most long-term gay and lesbian relationships as we have discussed them: most long-term partners would probably accept the obligation to meet each other's most basic needs, ${ }^{159}$ and many would be affected both financially and emotionally by the death of their spouse, and, when they are so affected, deserve compensation from a wrongful actor.

\section{OBSERVATIONS}

American states and the federal government, as we now have seen, treat married individuals differently than single individuals in three broad respects - privileging their relationship to their spouse in certain contexts because of their affective ties, providing them and their partners opportunities for legally recognized parenting that are not provided to others, and extending benefits and imposing obligations based on a view of the partners as economically intertwined.

Taken together, the rules bearing on marriage offer significant advantages to those to whom they apply. Looking across the three groups of regulations we have examined, most of the rules may be seen as facilitative, in the sense that they enable a couple to live a life that they define as satisfactory to themselves: the immigration law permits them to live together in the United States, if that is what they wish; the joint income tax return and the Social Security laws make it easier for one of them not to work in the labor force, if that is what they wish; the parenting laws offer them the opportunity to raise a child as legal

156. See 1 CLARK, supra note $18, \S 7.3$, at $444-48$. For a recent example of a hospital recovering from a wife for services provided to a spouse, even after the couple had separated, see Forsyth Memorial Hosp. Inc. v. Chisholm, 22 Fam. L. Rep. (BNA) 1185 (N.C. Feb. 2, 1996).

157. See CUNNINGHAM ET AL., supra note 116, § 5.16, at 242-43; MCClanAHAN, supra note $116, \S \S 4: 31-4: 36$.

158. As to wrongful death, see, e.g., SPEISER ET AL., supra note 155, $\S 10: 21$.

159. Hundreds of gay male and lesbian couples in San Francisco have registered their relationships as domestic partners under the city's Domestic Partnership Act. See San Francisco, CA., Admin. Code $\$ \S 62.1$ - 62.8 (1991). In order to register, couples must affirm that they accept responsibility for each others' "basic living expenses." San Francisco, CA., Admin. Code § 62.2(a) (1991). 
equals, if that is what they wish. The laws may also be seen as facilitative in a different sense. Some impose particular outcomes, but also permit the married partners to agree on some other arrangement if they so choose. Indeed, the laws of marriage can be seen today as facilitating choice in an even broader sense. Since living together outside of marriage is a socially acceptable arrangement today for so many couples heterosexual as well as lesbian and gay - the regime of marriage offers a package that can be taken as a whole or rejected in favor of the alternative state of unmarried coupledom, with its different, less pervasive set of rules. The case I have tried to make for gay and lesbian couples is that they need these opportunities and choices to much the same degree that heterosexual couples do.

The rules of marriage are not simply facilitative, however. Some rules relating to financial matters are mandatory. Your income is taken into account when your spouse applies for welfare. Your spouse, unless he chooses to relinquish it, becomes entitled upon divorce to share in the property you acquired in your name during the marriage, and, if you die, to a share of your estate. You may be forced to pay alimony to support your spouse. You may be forced to pay for necessities provided to your spouse by others. I have also sought to show that these obligations are, on the whole, appropriate for gay and lesbian couples. And even these mandatory rules can be seen as permissive in the wider sense in which it was used in the preceding paragraph: they are part of the whole package of rules that opposite-sex couples can choose to live within by marrying or live outside of by not marrying. Same-sex couples need the same choices.

Heterosexual conservatives object to same-sex marriage either on the ground that sex between persons of the same sex is immoral or pathological or on the ground that permitting same-sex couples to marry will somehow contribute to the crumbling of the "traditional" family. Feminists among gay and lesbian scholars are also often critical of marriage for same-sex couples, fearing different undesirable consequences for lesbian and queer communities. ${ }^{160}$ Neither objecting group focuses on the fit of specific legal rules with the lives of same-sex couples and, for this reason, this article has not addressed their claims. Four other sorts of doubts that do address the legal consequences of marriage might nonetheless be raised about legal same-sex marriage, even by some gay men and lesbians who might be expected to be sympathetic. I end this article by addressing those doubts.

160. See supra notes $11-12$. 
One doubt is not about the present, but about the future. It may be the case that the rules of marriage as they are today fit reasonably well the circumstances of gay men and lesbians in couples, but marriagerelated rules are hardly static. As in the past, they will change over time: ${ }^{161}$ a lesbian couple who marry in the year 2000 might find themselves subject to quite different rules in the year 2020. The future changes in law that they experience will almost certainly be prompted by the perceived conditions of women and men in opposite-sex couples and not by the positions of lesbians and gay men, because lesbian and gay couples are simply so outnumbered by female-male couples. Nonetheless, though many different legal changes are possible over time, some more attractive than others, ${ }^{162}$ marriage as a legal institution is highly likely to retain useful advantages for same-sex couples. These advantages will persist so long as adults in this country choose to live primarily in couple relationships and so long as doing so remains a socially prized condition. Gay people are likely to benefit by having the opportunity to choose to share in the benefits and responsibilities accorded such relationships. They will simply have to recognize that, when they do choose to marry, they will be stepping aboard a moving vessel that others will steer.

A second objection is that there is a better vehicle than something called "marriage" for extending the appropriate protections and opportunities to same-sex couples. Especially for those for whom marriage is indelibly associated with hierarchical male-female relationships, the alternative of permitting same-sex and opposite-sex couples to register with the state as "domestic partners" and extending to such partners some or all of the consequences attached to marriage may seem attractive.

No American state has yet adopted domestic partner registration, ${ }^{163}$ but, as we have seen, some states, through imaginative court decisions and occasional statutes, are beginning to recognize unmarried couples

161. On the flexibility of marriage as an institution through time, see John Modell, Historical Reflections on American Marriage, in CONTEMPORARY MARRIAGE: COMparative Perspectives on a Changing Institution 181 (Kingsley Davis ed., 1985).

162. See the discussion of various commentators in Elizabeth S. Scott, Rehabilitating Liberalism in Modern Divorce Law, 1994 UTAH L. Rev. 687, 708-19; see also June Carbone, Income Sharing: Redefining Family in Terms of Community, 31 Hous. L. REV. 359 (1994).

163. A substantial number of cities, including New York, San Francisco, Minneapolis, and Ann Arbor have adopted registration for unmarried couples by local ordinance. The California legislature passed a bill to permit state registration of unmarried couples, but the bill was vetoed by Governor Wilson. CA A.B. 2810, 1993-94 Reg. Sess. 
for particular purposes. ${ }^{164}$ Formal registration has been instituted in Denmark and Norway, where registered same-sex partners are treated precisely like married couples with regard to all financial and economic regulations, but are not labelled as "married." 165 This is not the place to discuss the whole range of practical and symbolic considerations that apply to domestic partnership. The point derived from the inquiry in this article is that whatever the virtues of domestic partnership, nearly all the legal consequences of marriage have a sound application to the position of long-term lesbian and gay couples. Unless a regime of domestic partnership were developed under which same-sex couples were treated just as opposite-sex married couples are, same-sex couples would probably find that domestic partnership legislation excluded benefits that they would much like to have. Thus, in Denmark, for example, registered same-sex couples are treated like opposite-sex married couples for purposes of economic benefits, but not for purposes of the adoption laws or any other laws that apply to parenting.

I do not, however, wish to seem critical of the movement for domestic partnership registration. I believe that, though the rose by another name will not smell as sweet to some of us, states are far more likely to accept domestic partnership than same-sex marriage. Denmark - and the fifty American states - may eventually accept for gay couples united under a name other than "marriage" all the special rules for married persons, including those that apply to parenting. And those of us who favor legal same-sex marriage must acknowledge that just as "domestic partnership" legislation might provide only parts of the package of legal consequences that now attaches to marriage, so also legal "marriage" itself might be granted piecemeal as well: a state might open legal marriage to same-sex couples but withhold parenting or other benefits from them, or, more fundamentally, some states might extend all state laws bearing on marriage to same-sex couples while the federal government withheld the incidents of federal law. ${ }^{166}$

A third doubt about pursuing changes in the laws of who may marry is that the benefits of marriage are likely to be unevenly distributed among same-sex couples. Nitya Duclos, a Canadian scholar, has argued, for example, that the rules of marriage would primarily benefit

164. See, e.g., supra text accompanying notes $34,35,75,139-42$. For a recent general discussion of the recognition of nonmarital relationships in the United States, see Jana B. Singer, The Privatization of Family Law, 1992 WIS. L. REv. 1443, 144756.

165. See The Danish Registered Partnership Act, No. 372 (1989); Norwegian Act on Registered Partnerships for Homosexual Couples (1993).

166. See supra text accompanying note 2 . 
lesbians and gay men who are members of the middle class - "those who are already fairly high up in the hierarchy of privilege." 167 She does not argue that this lopsided allocation of benefits is a reason not to permit same-sex marriage, for surely it is not, but rather is a reason to be less exultant about what will be achieved by it. ${ }^{168}$

Duclos may possibly be right. Those high in the hierarchy of privilege usually come out ahead. Still, at least in this country, many lowerincome same-sex couples will find great benefits in marriage. Duclos claims that " $[t]$ hose who rely for most of their income on state benefits are more likely [than middle class persons] to be economically penalized for marrying," 169 and it is true that a significant cost of marriage for some lower-income persons who marry a working person is the loss of governmental benefits, such as Medicaid or Supplemental Security Income. ${ }^{170}$ It is also true that some other rules, such as those exempting bequests to a spouse from the estate and gift taxes, are of value only to those who have large sums to give away. Still, there may be compensating gains for low income persons. Social Security retirement benefits for a nonworking spouse and Social Security survivor benefits are of most importance to those without long ties to the formal economy. Medical benefits tied to employment - including employment of some low-earning government employees - are of immense significance to spouses with jobs that carry no health coverage at all. And other benefits, such as the immigration rules or rules that relate to intestate succession, are likely to be at least as frequently invoked by the people of modest incomes as they are by the well-heeled. It is impossible for all sorts of reasons to make a confident prediction of what class-groups among gay men and lesbians would benefit most from being permitted to marry, but there is ample reason to believe that the rules relating to marriage will be appealing to many people of all classes.

A final criticism of the laws bearing on married persons is more fundamental: even if legal marriage would offer benefits to a broad range of same-sex couples, some might claim that all these advantages are illegitimate - illegitimate for both same-sex and opposite-sex couples - because they favor persons in two-person units over single persons and over persons living in groups of three or more, and because they favor persons linked to one other person in a sexual-romantic relationship over persons linked to another by friendship or other alle-

167. Nitya Duclos, Some Complicating Thoughts on Same-Sex Marriage, 1 L. \& SeXuality 31, 55, 58 (1991).

168. Id. at 59.

169. Id. at 55 .

170. See supra text accompanying notes $100-01$. 
giances. ${ }^{171}$ Those of us who are gay or lesbian must be especially sensitive to these claims. If the deeply entrenched paradigm we are challenging is the romantically linked man-woman couple, we should respect the similar claims made against the hegemony of the two-person unit and against the romantic foundations of marriage.

Governments nonetheless seem justified in favoring a special relationship with someone known as a spouse over other relationships of friendship or kinship in those contexts in which friendship or kinship alone rarely leads to the sorts of intermingling of assets or joint undertakings to raise children that commonly occur for persons who regard themselves as long-term lovers or spouses. Most of the rules for forced sharing of property or for advantages in adoption rest on perceptions of the understandings and desires of the enduring couple that much less often aptly apply to relationships with friends or other kin. Still, there are many occasions when greater recognition should be permitted for friendship or other kinship relations than currently obtains. Two siblings who live together and who have raised a deceased sibling's child ought to be eligible, for example, to adopt the child. A single person ought to be able to register a person as a special friend and obtain at least some benefits now provided for a spouse. Under the Federal Family and Medical Leave Act, for example, a single, childless person currently has no right to take time off to care for someone he loves other than a parent. A system of advance registration of a friend for whose care the statutory privilege would extend seems both feasible and desirable.

As to the privileging of the two-person romantic unit of husband and wife over romantically linked units of other sizes, I am equally queasy. Rather few such cohabiting relationships of three or more appear to exist in this country, whether for mixed-sex or same-sex groups. ${ }^{172}$ Reasons can be offered why the state should recognize the two-person marriage but not the marriage of three or more, but I do not wish to try. In the end, most of the reasons are logistical and soluble. ${ }^{173}$ If the law of marriage can be seen as facilitating the opportunities of two people to live an emotional life that they find satisfying - rather

171. See Weston, supra note 46 , at 209-10; Homer, supra note 11 , at 530; Jaff, supra note 90 , at $238-42$.

172. I've always been surprised that there were not more three and more person cohabiting units among gay men and lesbians, since homosexual people are, after all, already flouting convention when living together in pairs.

173. Justifiable limits could, for example, be placed on the number of spouses one could bring into the country on a privileged basis. Rules could be fashioned for the division of assets among three or four people who are splitting. 
than as imposing a view of proper relationships - the law ought to be able to achieve the same for units of more than two.

However, the fact that the state unwisely ignores or prohibits certain relationships in addition to those of lesbian and gay couples does not make it inappropriate to advocate for the recognition of gay and lesbian couple relationships today. Nearly all reform to correct disparate treatment in our society is incremental. It comes at points at which the state finally recognizes the legitimacy of the claims of some long disfavored group. Thus, within this century, governments have gradually changed their posture toward the legal position of the child born outside of marriage and toward unmarried opposite-sex couples in their relationships with one another.

A next appropriate step is the step discussed in this article - the recognition of same-sex couples who wish to marry. And although it is conceivable, as some have feared, that permitting gay people to marry will simply reinforce the enshrined position of married two-person units in general in our society, it seems at least as likely that the effect of permitting same-sex marriage will be to make society more receptive to the further evolution of the law. ${ }^{174}$ By ceasing to conceive of marriage as a partnership composed of one person of each sex, the state may become more receptive to units of three or more (all of which, of course, include at least two persons of the same sex) and to units composed of two people of the same sex but who are bound by friendship alone. All desirable changes in family law need not be made at once.

174. See Nan D. Hunter, Marriage, Law and Gender: A Feminist Inquiry, 1 L. \& SEXUALITY 9, 12 (1991). 